\title{
Response and Toxicity to Cytarabine Therapy in Leukemia and Lymphoma: From Dose Puzzle to Pharmacogenomic Biomarkers
}

\author{
Raffaele Di Francia ${ }^{1}\left(\mathbb{D}\right.$, Stefania Crisci ${ }^{2}{ }^{(1)}$, Angela De Monaco ${ }^{3}$, Concetta Cafiero ${ }^{4, *}$, Agnese Re $^{5}$, \\ Giancarla Iaccarino ${ }^{2}$, Rosaria De Filippi ${ }^{2,6}$, Ferdinando Frigeri ${ }^{7}$, Gaetano Corazzelli ${ }^{2}$, Alessandra Micera ${ }^{8, *}$ \\ and Antonio Pinto ${ }^{2}$
}

check for updates

Citation: Di Francia, R.; Crisci, S.; De Monaco, A.; Cafiero, C.; Re, A.; Iaccarino, G.; De Filippi, R.; Frigeri, F.; Corazzelli, G.; Micera, A.; et al. Response and Toxicity to Cytarabine Therapy in Leukemia and Lymphoma: From Dose Puzzle to Pharmacogenomic Biomarkers. Cancers 2021, 13, 966. https:// doi.org/10.3390/cancers13050966

Academic Editor: Franz Rödel

Received: 17 January 2021

Accepted: 19 February 2021

Published: 25 February 2021

Publisher's Note: MDPI stays neutral with regard to jurisdictional claims in published maps and institutional affiliations.

Copyright: (c) 2021 by the authors. Licensee MDPI, Basel, Switzerland. This article is an open access article distributed under the terms and conditions of the Creative Commons Attribution (CC BY) license (https:/ / creativecommons.org/licenses/by/ $4.0 /)$.
1 Italian Association of Pharmacogenomics and Molecular Diagnostics, 60126 Ancona, Italy; rdifrancia@iapharmagen.org

2 Hematology-Oncology and Stem Cell transplantation Unit, National Cancer Institute, Fondazione "G. Pascale" IRCCS, 80131 Naples, Italy; s.crisci@istitutotumori.na.it (S.C.); g.iaccarino@istitutotumori.na.it (G.I.); rdefilip@unina.it (R.D.F.); g.corazzelli@istitutotumori.na.it (G.C.); a.pinto@istitutotumori.na.it (A.P.)

3 Clinical Patology, ASL Napoli 2 Nord, "S.M. delle Grazie Hospital", 80078 Pozzuoli, Italy; angela.demonaco@aslnapoli2nord.it

4 Medical Oncology, S.G. Moscati, Statte, 74010 Taranto, Italy

5 Università Cattolica del Sacro Cuore, 00168 Rome, Italy; agnese.re@unicatt.it

6 Department of Clinical Medicine and Surgery, Federico II University, 80131 Naples, Italy

7 UOC Onco-Hematology, AORN SS Anna e Sebastiano, 81100 Caserta, Italy; ferdinando.refrigeri@ospedale.caserta.it

8 Research and Development Laboratory for Biochemical, Molecular and Cellular Applications in Ophthalmological Sciences, IRCCS—Fondazione Bietti, 00184 Rome, Italy

* Correspondence: concetta.cafiero@asl.taranto.it or concettacafiero@gmail.com (C.C.); alessandra.micera@fondazionebietti.it (A.M.); Tel.:+39-34-0101-2002 (C.C.); +39-06-4554-1191 (A.M.)

Simple Summary: In this review, the authors propose a crosswise examination of cytarabine-related issues ranging from the spectrum of clinical activity and severe toxicities, through updated cellular pharmacology and drug formulations, to the genetic variants associated with drug-induced phenotypes. Cytarabine (cytosine arabinoside; Ara-C) in multiagent chemotherapy regimens is often used for leukemia or lymphoma treatments, as well as neoplastic meningitis. Chemotherapy regimens can induce a suboptimal clinical outcome in a fraction of patients. The individual variability in clinical response to Leukemia \& Lymphoma treatments among patients appears to be associated with intracellular accumulation of Ara-CTP due to genetic variants related to metabolic enzymes. The review provides exhaustive information on the effects of Ara-C-based therapies, the adverse drug reaction will also be provided including bone pain, ocular toxicity (corneal pain, keratoconjunctivitis, and blurred vision), maculopapular rash, and occasional chest pain. Evidence for predicting the response to cytarabine-based treatments will be highlighted, pointing at their significant impact on the routine management of blood cancers.

Abstract: Cytarabine is a pyrimidine nucleoside analog, commonly used in multiagent chemotherapy regimens for the treatment of leukemia and lymphoma, as well as for neoplastic meningitis. AraC-based chemotherapy regimens can induce a suboptimal clinical outcome in a fraction of patients. Several studies suggest that the individual variability in clinical response to Leukemia \& Lymphoma treatments among patients, underlying either Ara-C mechanism resistance or toxicity, appears to be associated with the intracellular accumulation and retention of Ara-CTP due to genetic variants related to metabolic enzymes. Herein, we reported (a) the latest Pharmacogenomics biomarkers associated with the response to cytarabine and (b) the new drug formulations with optimized pharmacokinetics. The purpose of this review is to provide readers with detailed and comprehensive information on the effects of Ara-C-based therapies, from biological to clinical practice, maintaining high the interest of both researcher and clinical hematologist. This review could help clinicians in predicting the response to cytarabine-based treatments.

Keywords: Ara-C; pharmacogenetics; target therapy; mechanism of resistance 


\section{Introduction}

Cytarabine or Cytosine arabinoside (1- $\beta$-D-arabinofuranosylcytosine) is a deoxycytidine nucleoside analog renowned among the most effective antineoplastic agents in upfront and salvage programs for myeloid and lymphoid leukemias, as well as Hodgkin and Non-Hodgkin lymphomas [1-5]. Despite forty years of thorough clinical application, treatment advances as a result of on cytarabine-containing regimens have largely lagged. Patients with acute myeloid leukemia (AML) still have their overall survival below $30 \%$, due to both intrinsic and acquired chemotherapy resistance, and lymphoma patients benefit only of temporary disease control, without any definitive cure [6-8]. In the meanwhile, the load of severe, life-threatening, or lethal toxicities has remained substantial and mostly unpredictable [9-14]. Hence, the optimal efficacy and toxicity trade-off and appropriate clinical settings for cytarabine have remained partway undefined, even with continuous efforts to custom dose scheduling, and stratify prognostic host and tumor characteristics, including cytogenetic and molecular markers. Genetic dissimilarity with large inter-individual differences on pharmacokinetics, as well as pharmacodynamics have been unveiled for various chemotherapeutic agents by pharmacogenetic studies through candidate-genes approaches focusing on drug metabolism. Pharmacogenomics data on genetic and molecular determinants of response were obtained at tumor level by means of newer genome-wide association (GWA) studies. Germline genetic variants have been associated with chemotherapy-induced phenotypes and used to predict toxicity as in the illustrative example of thiopurine methyl-transferase enzyme activity, a major determinant of the activity of the adenine analog 6-mercaptopurine in leukemias and bowel inflammatory diseases. Since the conventional dose of 6-mercaptopurine produces life-threatening toxicity in individuals with certain alleles variants of thiopurine $\mathrm{S}$ methyltransferase, the detection of thiopurine $S$ methyltransferase gene mutations is now recommended, and individuals with non-functional alleles can be efficiently treated with reduced doses of 6-mercaptopurine [15].

The metabolism and mechanism of action of cytarabine are directly linked to the biotransformation of its physiological deoxyribonucleotide counterpart, the natural nucleoside deoxycytidine, including membrane transportation, intracellular activation, and interaction with cellular targets. Gene products involved in this process have been well characterized and include transporters of solute carriers (SLC) and ATP-binding cassette (ABC) families, activators such as deoxycytidine kinase (DCK), nucleoside diphosphate kinase (NDK), and ribonucleotide reductase, as well as the catabolyzers of cytidine deaminase (CDA) and 5-nucleotidases [16,17].

Genetic variants for cytarabine-metabolizing enzymes and carriers have been identified, and coding or regulatory polymorphisms have been proposed of functional significance and clinical relevance, so advocating properly devised trials to validate putative associations with phenotypes of toxicity or chemo-resistance [18]. Specific panels of genetic determinants for response and toxicity can be derived for clinical testing, to tailor treatment preventing severe toxicities or diverting treatment in cases of drug-resistance. However, the application of pharmacogenomics to cytarabine treatment is still hindered by the inadequate diffusion and affordability of genotyping methods in routine clinical diagnostics, challenges in statistical validation, and hazy evidence that pharmacogenetics and genomics testing improve patients' outcomes $[19,20]$. In the meantime, the understanding of underlying processes of cytarabine intracellular metabolism through bioactivation and detoxication pathways has led to the development and active clinical investigation of new formulations of the drug with optimized pharmacokinetics [21].

In this article, the authors propose a crosswise examination of cytarabine-related issues, ranging from the spectrum of clinical activity and severe toxicities, through updated cellular pharmacology and drug formulations, to the genetic variants associated with druginduced phenotypes. The goal of this review is to give readers an all-round information 
on the effects of Ara-C based therapies, from biology to clinical practice. This issue could help oncologist to plan optimal dosage and combination with other drugs to make a personalized treatment.

\section{Spectrum of Clinical Uses and Serious Toxicities of Cytarabine}

The selective action against rapidly dividing cells and the lack of metabolic activation in solid tumors have ensued from broad activity, and focusing the application of hematological malignancies [22]. The current dosage and schedules in Leukemia and Lymphoma are a result of many years of trials, clinical observations, and predictive models [23].

\subsection{Leukemia}

Since 1974, cytarabine is used either alone or in combination with an anthracycline (daunorubicin or idarubicin) in virtually all induction regimens for acute myeloid leukemia (AML), and as a component of consolidation and maintenance programs after remission is attained (Table 1).

The incorporation of cytarabine is needed also in AML subtypes with exquisite susceptibility to anthracycline treatment, such as acute promyelocytic leukemia [24]. As a result of its short half-life and rapid plasmatic inactivation, different schedules and dose-levels of cytarabine have been adopted for intravenous infusion or injection of cytarabine in clinical practice (low, standard, high, and, more recently, intermediate cytarabine doses) while intrathecal administration is regularly employed for prophylaxis and treatment of meningeal leukemia and lymphoma [25-27] (Table 1). Although cytarabine is used most commonly in regimens of 100 to $200 \mathrm{mg} / \mathrm{m}^{2} / \mathrm{d}$ for 5 to 7 days, other high-dose and low-dose schedules have been used for treating leukemia. The clinical activity of low-dose cytarabine in AML has been evaluated particularly in older patients or with preexistent myelodysplasia [28,29]. These regimens adopted dosages in the range of 3 to $20 \mathrm{mg} / \mathrm{m}^{2} / \mathrm{d}$ for up to 3 weeks, with the expectation that low doses would produce less toxicity and promote leukemic cell differentiation (or apoptosis). In general, though the low-dose regimens produce less toxicity, in terms of myelosuppression, than previously hydroxyurea-based treatments [30].

The high-dose schemes, usually 2 to $3 \mathrm{~g} / \mathrm{m}^{2}$ every $12 \mathrm{~h}$ for up to six doses, was introduced about three decades ago, and, after the landmark CALGB study published in 1994, it became central to the improvement in the treatment of patients with AML [31,32]. In AML, high-dose cytarabine is used primarily in the consolidation phase [33] and upfront in patients with unfavorable, intrinsically drug resistant, oncogenic subtypes $(8 ; 21)$, inv16, del16, $t(16 ; 16)$ [33]. For the last two decades, high-dose cytarabine has been the optimal post-remission therapy for patients with AML in first remission not proceeding to allogenic transplantation $[34,35]$.

Due to concern of severe side effects, some researchers have recently suggested a possible replacement of high-dose cytarabine with an equally effective less toxic regimen delivering intermediate dosing $\left(1000 \mathrm{mg} / \mathrm{m}^{2}\right.$ for each dose), so to increase the therapeutic index of the drug $[36,37]$.

Recently, in patients not eligible for intensive Ara-C dosage, Venetoclax plus a lowdose Ara-C (LDAC) demonstrates clinically meaningful improvement in remission rate and Overall Survivor (OS) vs LDAC alone (\#NCT03069352) [38].

Venetoclax is a BCL2 inhibitor, this new class of drugs promising a manageable safety in optimized schedules combined to antimetabolites. 
Table 1. Overview of cytarabine dose intensities and schedules in regimens for acute myeloid leukemias in adults. Details concerning dosing in combination regimens should also be consulted.

\begin{tabular}{|c|c|c|c|c|}
\hline Disease & Phase & Regimens & Cytarabine Dosing and Additional Drugs & References \\
\hline \multirow[t]{13}{*}{$\begin{array}{l}\text { Acute myeloid } \\
\text { leukemia }\end{array}$} & induction & $7+3$ & $\begin{array}{c}100 \mathrm{mg} / \mathrm{m}^{2} / \text { day continuous infusion for } 7 \text { days (in combination } \\
\text { with daunorubicin or idarubicin or mitoxantrone) or (Adults }<60 \\
\text { years) } 200 \mathrm{mg} / \mathrm{m}^{2} / \text { day continuous infusion for } 7 \text { days (in } \\
\text { combination with daunorubicin) }\end{array}$ & [39-42] \\
\hline & & Low-Dose SubQ & $\begin{array}{l}\text { Adults } \geq 65 \text { years: SubQ: } 20 \mathrm{mg} / \mathrm{m}^{2} / \text { day for } 14 \text { days out of every } \\
28 \text {-day cycle for at least } 4 \text { cycles or } 10 \mathrm{mg} / \mathrm{m}^{2} \text { every } 12 \mathrm{~h} \text { for } 21 \\
\text { days, or } 10 \mathrm{mg} / \mathrm{m}^{2} \text { every } 12 \mathrm{~h} \text { for } 21 \text { days; may repeat after } 15 \text { days }\end{array}$ & {$[28,29]$} \\
\hline & consolidation & $5+2$ & $\begin{array}{c}100 \mathrm{mg} / \mathrm{m}^{2} / \text { day continuous infusion for } 5 \text { days (in combination } \\
\text { with daunorubicin or idarubicin or mitoxantrone) }\end{array}$ & {$[39,40]$} \\
\hline & & $5+2+5$ & $\begin{array}{c}100 \mathrm{mg} / \mathrm{m}^{2} / \text { day continuous infusion for } 5 \text { days (in combination } \\
\text { with daunorubicin and etoposide) }\end{array}$ & [43] \\
\hline & & $\begin{array}{l}\text { BCL2 inhibitor/LDAC } \\
\qquad 4+4\end{array}$ & $\begin{array}{l}\text { Venetoclax once daily, began at } 100 \mathrm{mg} \text { on day } 1 \text { and increased } \\
\text { stepwise over } 4 \text { days to reach the target dose of } 600 \mathrm{mg}(100,200 \text {, } \\
400 \text {, and } 600 \mathrm{mg} \text { ); dosing was continued at } 600 \mathrm{mg} \text { per day from } \\
\text { day } 4 \text { through day } 28 \text { in combination with } 20 \mathrm{mg} / \mathrm{m}^{2} \text { of Ara-C }\end{array}$ & {$[38]$} \\
\hline & & $\begin{array}{l}\text { High-Dose } \\
\text { single-agent }\end{array}$ & $\begin{array}{l}\text { Adults } \leq 60 \text { years: } 3000 \mathrm{mg} / \mathrm{m}^{2} \text { over } 3 \mathrm{~h} \text { every } 12 \mathrm{~h} \text { on days } 1,3, \\
\text { and } 5 \text { (total of } 6 \text { doses); repeat every } 28-35 \text { days for } 4 \text { courses }\end{array}$ & [32] \\
\hline & & Intermediate-dose & $\begin{array}{c}\text { cycle I: cytarabine } 200 \mathrm{mg} / \mathrm{m}^{2} \text { per continuous infusion on days } 1-7 ; \\
\left.\text { included idarubicin at } 12 \mathrm{mg} / \mathrm{m}^{2} \text { (3-h infusion on days } 5,6 \text { and } 7\right) ; \\
\text { cycle II: cytarabine } 1000 \mathrm{mg} / \mathrm{m}^{2} \text { intravenously for } 3 \mathrm{~h} \text { twice daily } \\
\text { on days 1-6; included amsacrine } 120 \mathrm{mg} / \mathrm{m}^{2} \text { per } 1 \text {-h infusion on } \\
\text { days } 3,5 \text { and } 7\end{array}$ & [37] \\
\hline & salvage & $A D E$ & $\begin{array}{c}100 \mathrm{mg} / \mathrm{m}^{2} \mathrm{I} . \mathrm{V} \text { push every } 12 \mathrm{~h} \text { for } 10 \text { days (in combination with } \\
\text { daunorubicin and etoposide) }\end{array}$ & [44] \\
\hline & & $C L A G$ & $\begin{array}{l}2000 \mathrm{mg} / \mathrm{m}^{2} / \text { day over } 4 \mathrm{~h} \text { for } 5 \text { days (in combination with } \\
\text { cladribine and G-CSF) }\end{array}$ & [45] \\
\hline & & $C L A G-M$ & $\begin{array}{l}2000 \mathrm{mg} / \mathrm{m}^{2} / \text { day over } 4 \mathrm{~h} \text { for } 5 \text { days (in combination with } \\
\text { cladribine, G-CSF, and mitoxantrone) }\end{array}$ & [46] \\
\hline & & FLAG & $\begin{array}{c}2000 \mathrm{mg} / \mathrm{m}^{2} / \text { day over } 4 \mathrm{~h} \text { for } 5 \text { days (in combination with } \\
\text { fludarabine and G-CSF) }\end{array}$ & [47] \\
\hline & & High-Dose & $3000 \mathrm{mg} / \mathrm{m}^{2}$ over $1 \mathrm{~h}$ every $12 \mathrm{~h}$ for 12 doses ( \pm an anthracycline) & [31] \\
\hline & & $M E C$ & $\begin{array}{c}1000 \mathrm{mg} / \mathrm{m}^{2} / \text { day over } 6 \mathrm{~h} \text { for } 6 \text { days (in combination with } \\
\text { mitoxantrone and etoposide)or Adults }<60 \text { years: } 500 \mathrm{mg} / \mathrm{m}^{2} / \text { day } \\
\text { continuous infusion days } 1,2 \text {, and } 3 \text { and days } 8,9 \text {, and } 10 \text { (in } \\
\text { combination with mitoxantrone and etoposide) }\end{array}$ & {$[48,49]$} \\
\hline $\begin{array}{l}\text { Acute } \\
\text { promyelocytic } \\
\text { leukemia }\end{array}$ & induction & $\begin{array}{l}\text { APL2000 } \\
\text { C9710 }\end{array}$ & $\begin{array}{l}200 \mathrm{mg} / \mathrm{m}^{2} / \text { day continuous infusion for } 7 \text { days beginning on day } 3 \\
\text { of treatment (in combination with tretinoin and daunorubicin) }\end{array}$ & {$[50,51]$} \\
\hline
\end{tabular}

Abbreviation: LDAC: low-dose Ara-C.

\subsection{Lymphoma}

Beyond the use in myeloid leukemia, cytarabine had a wide and established use, especially through the high-dose regimen, in upfront therapy against very aggressive lymphoproliferative disorders, such as acute lymphocytic leukemia and Burkitt and Burkittlike lymphomas [52-56] (Table 2). Cytarabine-containing regimens also has exquisite activity in the first-line treatment of mantle cell lymphoma and are going to represent a real new benchmark in this difficult to treat lymphoma subtype [57-59].

Notably, high-dose cytarabine has represented, in the last 20 years, a cornerstone of salvage programs for patients with recurrent Hodgkin and non-Hodgkin lymphoma, mostly in combination with platinating agents [60-63]. In the same setting of patients, it had been also employed for mobilizing peripheral stem cells and incorporated into cytoreductive high-dose therapy before autologous transplantation $[64,65]$ (Table 2). Since a high-dose regimen leads to high drug levels in the cerebrospinal fluid, this regimen may provide adequate prophylaxis for lymphomatous localization and integrate conventional intrathecal administration of cytarabine delivered at a low dose as a single agent or in combination with methotrexate and dexamethasone (Table 2). High dosage cytarabine is also an essential component of systemic therapy for primary lymphomas of the central nervous system (CNS) [66]. 
Table 2. Overview of cytarabine regimens including cytarabine for lymphoid neoplasms in adults. Details concerning doses in combination regimens should also be consulted.

\begin{tabular}{|c|c|c|c|c|}
\hline Disease & Phase & Regimens & Cytarabine Dosing and Additional Drugs & References \\
\hline \multirow[t]{3}{*}{$\begin{array}{l}\text { Acute lymphocytic } \\
\text { leukemia }\end{array}$} & induction & Hyper-CVAD & $\begin{array}{c}\text { Dose-intensive regimen: I.V.: } 3000 \mathrm{mg} / \mathrm{m}^{2} \text { over } 2 \text { h every } \\
12 \mathrm{~h} \text { days } 2 \text { and } 3 \text { ( } 4 \text { doses/cycle) of even numbered cycles } \\
\text { (in combination with methotrexate; alternates with } \\
\text { Hyper-CVAD) }\end{array}$ & [54] \\
\hline & & Larson regime $S u b Q$ & $\begin{array}{c}\text { Early intensification phase: } 75 \mathrm{mg} / \mathrm{m}^{2} / \text { dose days } 1 \text { to } 4 \text { and } \\
8 \text { to } 11 \text { (4-week cycle; repeat once) } \\
\text { Late intensification phase: } 75 \mathrm{mg} / \mathrm{m}^{2} / \text { dose days } 29 \text { to } 32 \\
\text { and } 36 \text { to } 39\end{array}$ & [67] \\
\hline & $\begin{array}{l}\text { induction, relapse or } \\
\text { progression }\end{array}$ & High-Dose & $\begin{array}{c}3000 \mathrm{mg} / \mathrm{m}^{2} \text { over } 3 \mathrm{~h} \text { daily for } 5 \text { days (in combination with } \\
\text { idarubicin [day 3]) }\end{array}$ & {$[68]$} \\
\hline $\begin{array}{l}\text { Chronic lymphocytic } \\
\text { leukemia }\end{array}$ & $\begin{array}{l}\text { refractory or Richter's } \\
\text { syndrome }\end{array}$ & OFAR & $\begin{array}{l}\text { I.V.: } 1000 \mathrm{mg} / \mathrm{m}^{2} / \text { dose over } 2 \mathrm{~h} \text { days } 2 \text { and } 3 \text { every } 4 \text { weeks } \\
\text { for up to } 6 \text { cycles (in combination with oxaliplatin, } \\
\text { fludarabine, and rituximab) }\end{array}$ & [69] \\
\hline \multirow[t]{2}{*}{$\begin{array}{l}\text { Burkitt and } \\
\text { Burkitt-like lymphoma }\end{array}$} & induction & CALGB 9251 & $\begin{array}{c}\text { Cycles 2, 4, and 6: } 150 \mathrm{mg} / \mathrm{m}^{2} / \text { day continuous infusion } \\
\text { days } 4 \text { and } 5\end{array}$ & {$[52,70]$} \\
\hline & & CODOX-M/IVAC & $\begin{array}{l}\text { Adults } \leq 65 \text { years: Cycles } 2 \text { and } 4 \text { (IVAC): } 2000 \mathrm{mg} / \mathrm{m}^{2} \text { over } \\
3 \mathrm{~h} \text { every } 12 \mathrm{~h} \text { days } 1 \text { and } 2 \text { (total of } 4 \text { doses } / \text { cycle) }(1000 \\
\mathrm{mg} / \mathrm{m}^{2} \text { if age }>65 \text { ) (IVAC is combination with ifosfamide, } \\
\text { mesna, and etoposide; IVAC alternates with CODOX-M) }\end{array}$ & [53] \\
\hline Mantle cell lymphoma & induction & $R-B A C$ & $\begin{array}{l}\text { cytarabine } 800 \mathrm{mg} / \mathrm{m}^{2} \mathrm{IV} \text { on days } 2 \text { to } 4 \text { ) every } 28 \text { days for } \\
\text { four to six cycles (in combination with rituximab and } \\
\text { bendamustine) }\end{array}$ & [57] \\
\hline $\begin{array}{l}\text { CNS lymphoma, } \\
\text { primary }\end{array}$ & induction & & $\begin{array}{l}\text { I.V.: } 2000 \mathrm{mg} / \mathrm{m}^{2} \text { over } 1 \mathrm{~h} \text { every } 12 \mathrm{~h} \text { days } 2 \text { and } 3 \text { (total of } 4 \\
\text { doses) every } 3 \text { weeks (in combination with methotrexate and } \\
\text { followed by whole brain irradiation) for a total of } 4 \text { courses }\end{array}$ & [66] \\
\hline \multirow[t]{4}{*}{$\begin{array}{l}\text { Hodgkin and } \\
\text { non-Hodgkin } \\
\text { lymphoma }\end{array}$} & relapse or progression & DHAP & $\begin{array}{c}2000 \mathrm{mg} / \mathrm{m}^{2} \text { over } 3 \mathrm{~h} \text { every } 12 \mathrm{~h} \text { day } 2 \text { (total of } 2 \\
\text { doses / cycle) for } 2 \text { cycles (in combination with } \\
\text { dexamethasone and cisplatin) }\end{array}$ & {$[62,71]$} \\
\hline & & ESHAP & $\begin{array}{c}2000 \mathrm{mg} / \mathrm{m}^{2} \text { day } 5 \text { (in combination with etoposide, } \\
\text { methylprednisolone, and cisplatin) every } 3 \text { to } 4 \text { weeks for } 3 \\
\text { or } 6 \text { cycles }\end{array}$ & {$[60,63]$} \\
\hline & & DHAOX & $\begin{array}{l}2000 \mathrm{mg} / \mathrm{m}^{2} \text { every } 12 \mathrm{~h} \text { day } 2 \text { (in combination with } \\
\text { dexamethasone, and oxaliplatin) every } 3 \text { weeks }\end{array}$ & [61] \\
\hline & & $B E A M$ & $\begin{array}{l}\text { transplant preparative regimen: } 200 \mathrm{mg} / \mathrm{m}^{2} \text { twice daily for } \\
4 \text { days beginning } 5 \text { days prior to transplant (in combination } \\
\text { with carmustine, etoposide, and melphalan) }\end{array}$ & [64] \\
\hline
\end{tabular}

\subsection{Toxicity Profiles}

The toxicity profile of cytarabine is highly dependent on the dose and schedule of administration. With a standard 7-day regimen, myelosuppression is dose-limiting. Leukopenia and thrombocytopenia have the raiders occurring between days 7 and 14 after drug administration, with cytopenia duration eventually influenced by the concomitant use of other cytotoxic agents or previous treatment with chemotherapy. Gastrointestinal toxicity usually manifests as a mild-to-moderate mucositis and diarrhea. Occasionally acute pancreatitis has been reported in patients receiving cytarabine as a continuous infusion and in patients treated with L-asparaginase [72,73]. The so-called 'cytarabine syndrome' may occur within $12 \mathrm{~h}$ after the start of drug infusion with the onset of fever, myalgia, joint and bone pain, maculopapular rash, keratoconjunctivitis, and occasional chest pain [74]. This syndrome most likely represents an allergic reaction to cytarabine because patients usually develop symptoms months after the first dose, and corticosteroids can prevent its onset. Symptoms usually resolve within $24 \mathrm{~h}$ when cytarabine is discontinued as in pediatric patients [75].

With the administration of cytarabine at high doses (2 to $3 \mathrm{~g} / \mathrm{m}^{2}$ with each dose), common major side effects include biphasic pancytopenia, central nervous system toxicity, skin eruptions, and hyperbilirubinemia in more than $10 \%$ of patients while infection may affect two thirds of patients contributing to a treatment-related mortality rate of approximately 5\% [32,76]. When present, skin eruptions is often followed by fever. Notably, the rate of severe central nervous system adverse events (e.g., somnolence and confusion, 
and rarely seizures, cerebral dysfunction, acute cerebellar syndrome) is approximately $12 \%$ of overall patients, but it rises approximately to $30 \%$ in patients over the age of 60 , $40 \%$ of whom may be left with a permanent disability [77]. Acute cerebellar toxicity manifests as dysarthria with truncal and gait ataxia or less commonly as a cerebral syndrome manifesting as encephalopathy, psychosis, seizures, and coma. The pathogenesis of this syndrome is unknown, but there is widespread loss of Purkinje cells in the cerebellum [78]. The characteristic syndrome begins with somnolence and occasionally an encephalopathy that develops two to five days after beginning treatment. It may also be delayed, occurring up to 3-8 days after treatment has begun. The severe cerebellar toxicity may cause treatment discontinuation in a low subset of patients [78]. High-dose cytarabine may infrequently cause also peripheral neuropathies resembling Guillain-Barré syndrome, brachial plexopathy, lateral rectus palsy, optic neuropathy, or an extrapyramidal syndrome [79-81]. Risk factors for neurotoxicity include cumulative cytarabine dose, prior CNS disease and renal impairment (incidence may be up to $55 \%$ in patients with renal impairment); high-dose therapy ( $>18 \mathrm{~g} / \mathrm{m}^{2}$ per cycle) and age higher than 50 years also increases the risk for cerebellar toxicity $[77,82]$. Cases of fatal cardiomyopathy had been reported when high-dose cytarabine was used in combination with cyclophosphamide as a preparation regimen for transplantation [83]. Anaphylaxis resulting in acute cardiopulmonary arrest has been reported as well as sudden respiratory arrest syndrome occurring 6 to $12 \mathrm{~h}$ following drug administration. With high dose regimen, gastrointestinal toxicity can lead to bowel necrosis and esophagus ulceration, and the rate and severity of pulmonary side-effects are more pronounced, although not clear in their pathogenesis. A "cytarabine lung" is characterized by subacute respiratory failure accompanied by diffuse changes on chest radiographs, and the diagnosis is usually made when other explanations (such as infection) can be excluded [84]. With cytarabine intrathecal administration, severe adverse events are relatively uncommon. A transverse myelitis may occur similarly to those seen with intrathecal methotrexate administration, and rarely, it has been associated with aseptic meningitis, encephalopathy, headaches, and seizures [79,85]. When cytarabine injection in the cerebrospinal fluid (CSF) overlaps with systemic high-dose methotrexate and high-dose Cytarabine intravenously, there is an increased risk of spinal cord toxicity [86].

Ocular toxicity has been observed with high-dose cytosine arabinoside $\left(3.0 \mathrm{~g} / \mathrm{m}^{2}\right.$ every $12 \mathrm{~h}$ ). In some cases, patients referred excessive tearing, photophobia, burning ocular pain and blurred vision, and the ophthalmologic examination confirmed the presence of conjunctival injection, central punctate corneal opacities with subepithelial granular deposits, and decreased visual acuity, all treatment-limiting adverse effect of therapy. At molecular level, it has been suggested that the inhibition of corneal epithelial DNA synthesis due to drug dosage and time of drug exposure.

\section{Clinical Pharmacology and Cellular Metabolism of Cytarabine}

Cytarabine is not administered orally because of the high first-pass elimination in the liver and intestinal metabolism due to the presence of CDA that provide a rapid deamination into the inactive metabolite arabinosyl uracil. Once administered intravenously, Ara-C entries into the cells via specific membrane transport proteins [87]. The bulk of cytarabine deamination is thought to occur in the liver, spleen, and kidney, which have very high activities of CDA. Cytidine deaminase is present in plasma, though, at relatively low activity, while is almost absent in central nervous system. Males have a significantly faster clearance than females [88]. The standard or conventional dose, which ranges from 100 to $200 \mathrm{mg} / \mathrm{m}^{2}$ daily and is given by intermittent injection or continuous infusion over 5 to 10 days, achieves steady state plasma concentrations generally in the range of 0.1 to $0.5 \mu \mathrm{M}$. In the high-dose protocols with dose equal or exceeding $2 \mathrm{~g} / \mathrm{m}^{2}$, peak concentrations of cytarabine reach $100 \mu \mathrm{M}$.

Due to its hydrophilic properties, cytarabine requires transport into the cells and subsequent intracellular metabolic activation through sequential phosphorylation up to the cytotoxic triphosphate active form, which is incorporated into DNA, as false precursor 
in place of deoxycytidine triphosphate. This results in inhibition of DNA polymerase, chain termination and stalling DNA and RNA synthesis with the consequent blockage of the cell cycle from $\mathrm{G}_{1}$ to the $\mathrm{S}$ phase and neoplastic cell death (www.kegg.jp/kegg-bin/ showpathway?hsa00240+4830 (accessed on 13 January 2021)) [89,90].

The different phases of drug uptake, activation, and deactivation, are described in detail after wards and synoptically resumed in Table 3 together with key features of cytarabine pharmacology.

Table 3. Essential features of cytarabine pharmacology.

\begin{tabular}{|c|c|}
\hline Factor & Result \\
\hline Mechanism of action & $\begin{array}{l}\text { The active form, cytarabine triphosphate, induces miscoding after incorporation into DNA, terminates DNA } \\
\text { chain elongation and inhibits DNA polymerase }\end{array}$ \\
\hline Cellular influx and transporters & $\begin{array}{l}\text { Free diffusion into the cell if plasma concentration }>10 \mu \mathrm{M} \text { which is achieved with high-dose cytarabine } \\
\text { Nucleoside transporters required if plasma concentration }<1 \mu \mathrm{M} \text { which is achieved with } 100-200 \mathrm{mg} / \mathrm{m}^{2} \text { daily } \\
\text { (hENT1 responsible for up to } 80 \% \text { influx; hENT2, hCNT3, ABCC10 and ABCC11 transporters also involved) }\end{array}$ \\
\hline Metabolism enzymes & $\begin{array}{c}\text { Stepwise phosphorylation of cytarabine in tumor cells at the } 5^{\prime} \text { position of arabinoside up to triphosphate form by } \\
\text { Deoxycytidine kinase }(\rightarrow \text { cytarabine monophosphate }) \\
\text { Deoxycytidine momophosphate kinase }(\rightarrow \text { cytarabine diphosphate) } \\
\text { Nucleoside diphosphate kinase }(\rightarrow \text { cytarabine triphosphate }) \\
\text { Cytidinedeaminase (cytarabine } \rightarrow \text { uracilarabinoside) } \\
\text { Irreversible deamination of cytarabine and its monophosphate derivatives by } \\
\text { Deoxycytidine momophosphate deaminase (cytarabine monophosphate } \rightarrow \text { arabinosyluracil monophosphate) } \\
\text { Catalytic dephosphorilation of cytarabine monophosphate by } \\
\text { Cytosolic5'-nucleotidase II(cytarabinemonophosphate } \rightarrow \text { cytarabine) }\end{array}$ \\
\hline Pharmacokinetics & Plasma t $\frac{1}{2} \alpha 7-20 \mathrm{~min}, \mathrm{t} \frac{1}{2} \beta 1-3 \mathrm{~h} ; \mathrm{CSFt} \frac{1}{2} 2-6 \mathrm{~h}$ \\
\hline Elimination & $\begin{array}{l}\text { Dose rate ranging from } 86 \% \text { to } 96 \% \text { is deaminated to inactive uracil arabinoside Deamination in liver, plasma, and } \\
\text { peripheral tissue } \\
\text { Intrathecal administration results in little conversion to uracil arabinoside due to the low level of deaminase in the } \\
\text { cerebral spinal fluid } \\
\text { Escretion: urine }(\sim 80 \% ; 90 \% \text { as metabolite uracil arabinoside) within } 24 \mathrm{~h}\end{array}$ \\
\hline Drug interactions & $\begin{array}{l}\text { Methotrexate and fludarabine increase cytarabine triphosphate formation } \\
\text { Cytarabine blocks DNA repair and enhances activity of alkylating agents }\end{array}$ \\
\hline Myelosuppression & $\begin{array}{l}\text { Neutropenia (onset: } 1-7 \text { days; nadir [biphasic]: } 7-9 \text { days and at } 15-24 \text { days; recovery [biphasic]: } 9-12 \text { days and at } \\
24-34 \text { days); thrombocytopenia (onset: } 5 \text { days; nadir: } 12-15 \text { days; recovery } 15-25 \text { days); megaloblastosis }\end{array}$ \\
\hline Severe adverse events of high dose regimen & $\begin{array}{l}\text { Neurologic: cerebellar toxicity, coma, personality changes, cognitive dysfunctions, neurotoxicity (up to } 55 \% \text { in } \\
\text { patients with renal impairment), motor and sensor peripheral neuropathy } \\
\text { Gastrointestinal: esophageal and intestinalulceration, bowel necrosis, hepatic sinusoidal obstruction syndrome, } \\
\text { pancreatitis, pneumatosis cystoides intestinalis } \\
\text { Cutaneous: skin eruptions and ulceration, exanthematous pustulosis } \\
\text { Ocular: vision loss, keratitis, hemorrhagic conjunctivitis } \\
\text { Cardiopulmonary: non-cardiogenic pulmonary edema, syndrome of sudden respiratory distress, interstitial } \\
\text { pneumonitis, cardiomiopathy (in combination with cyclophosphamide) } \\
\text { Sepsis }\end{array}$ \\
\hline
\end{tabular}

\subsection{Drug Uptake}

Cytarabine gains entry into cells primarily as a false substrate through specialized nucleoside transporter proteins of SLC family, the human equilibrative nucleoside transportershENT1 and hENT2 (encoded by the gene SLC29A1 and SCL29A2, respectively) [91-94] and the human concentrative nucleoside transporters hCNT3 (encoded by the gene SLC28A3) [95-98]. Uptake and accumulation of cytarabine is also regulated by transmembrane transporter proteins of the $\mathrm{ABC}$ family, also called human multidrug resistance-associated protein (MRP) family, namely ABCC10 (MRP7) and ABCC11 (MRP8) specifically committed to efflux of deoxynucleotides inactive metabolites and to temper intracellular pools of phosphorylated deoxynucleotides (Figure 1) [99,100].

The integral drug uptake depends on the proper balance of the nucleoside transporters and drug efflux proteins presented on cellular membranes. Therefore, the drug accumulation may be substantially reduced when the expression of hENT1 transporter is deficient, or the activity of $\mathrm{ABC}$ drug efflux transporter proteins is elevated.

Cytarabine influx into the cells is strongly correlated with the cell surface abundance of hENT1 transporters [101], so that these membrane proteins are pharmacological determinants for drug bioavailability and response to treatment [102]. The expression of hENT1 can be regulated by the presence on the hENT1 promoter of hypoxia inducible factor 1 (Hif-1) binding sites [103] and according to more recent research, by the nuclear 
transcription factor peroxisome proliferator activated receptor $\alpha$ (PPAR $\alpha)$ [104]. Reduced hENT1 expression and activity has been related with unfavorable therapeutic outcomes in patients with acute myeloid leukemia treated with cytarabine $[105,106]$.

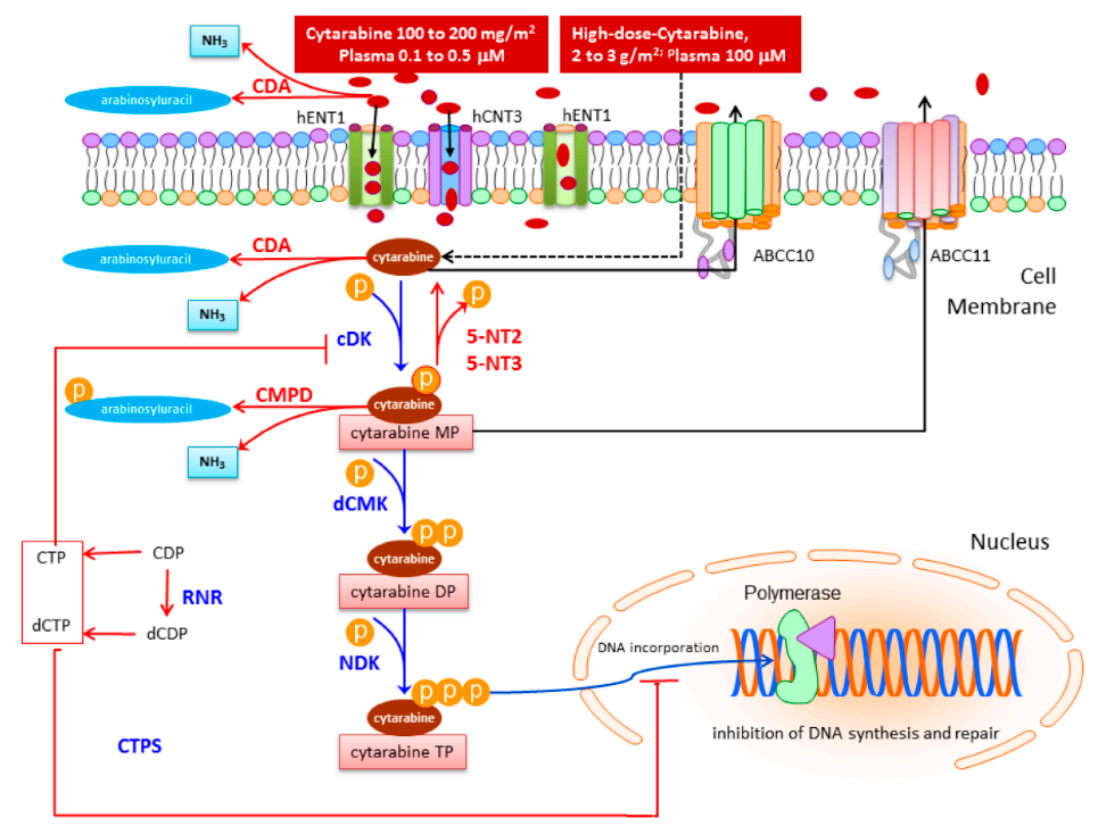

Figure 1. As with other nucleoside analogues and their physiologic counterparts, cytarabine enters cells via nucleoside transport proteins, the most important one being the equilibrative inhibitorsensitive (es) receptor $(A B C)$. Once inside the cell, cytarabine requires activation for its cytotoxic effects. The first metabolic step is the conversion of cytarabine to cytarabine monophosphate by the enzyme deoxycytidine kinase (DCK). Cytarabine is subsequently phosphorylated to cytarabine diphosphate and cytarabine triphosphate, respectively. Cytarabine triphosphate is a potent inhibitor of DNA polymerases, which, in turn, interferes with DNA chain elongation, DNA synthesis, and DNA repair. In addition, cytarabine is incorporated directly into DNA and functions as a DNA chain terminator, interfering with chain elongation. Catabolism of cytarabine involves two key enzymes, cytidine deaminase (CDA) and deoxycytidyne monophosphate deaminase (DCMD). These breakdown enzymes convert cytarabine and cytarabine monophosphate into the inactive metabolites, uracil arabinoside and arabinosyluracil monophosphate, respectively. Other catabolic enzymes that may affect cytarabine metabolism include pyrophosphatase, 5-nucleotidase. The balance between intracellular activation and degradation is critical in determining the amount of drug that is ultimately converted to cytarabine triphosphate and, thus, its subsequent cytotoxic and antitumor activity.

At drug concentrations above $10 \mu \mathrm{mol} / \mathrm{L}$, the pump-mediated transport process becomes saturated, so that further entry of cytarabine can takes place freely by passive diffusion $[107,108]$.

\subsection{Drug Activation}

Once inside the cells, as shown in Figure 1, activation of cytarabine occurs by means of the step wise de novo synthesis of 5'-mono-, di-, and triphosphate derivatives throughout the sequential action of deoxycytidine kinase (DCK), deoxycytidine monophosphate kinase (dCMK), and nucleoside diphosphate kinase (NDK) encoded by the NME1 gene [94,109]. Deoxycitidine kinase plays a pivotal role since phosphorylation of cytarabine preserves intracellular retention of the drug and prevents from inactivation to its uridine derivative, uracil arabinoside, by cytidine deaminase. The intracellular accumulation of cytarabine triphosphate, the active cytotoxic metabolite, is proportional to the cellular DCK level which has led to the conclusion that DCK enzyme retains a rate-limiting role for the 
activation of cytarabine [110]. Phosphorylated cytarabine metabolites interfere with the cellular pool of natural nucleosides, are incorporated into DNA and inhibit DNA synthesis in a competitive fashion [111]. Phosphorylated cytarabine metabolites interfere with the cellular pool of natural nucleosides, are incorporated into DNA and inhibit DNA synthesis in a competitive fashion [111]. This inhibition may be synergized with coadministration of others antimetabolites, such as fludarabine and cladribine. In particular, the Km of cytarabine triphosphate and physiological deoxycytidine triphosphate (dCTP) for DNA polymerase are in the same range, so that cytarabine-triphosphate can act as a weak competitive inhibitor of DNA polymerase $[112,113]$. After incorporation into DNA, cytarabine triphosphate behaves as a relative chain terminator and both replication and DNA repair are inhibited [114].

In vitro studies have revealed that the intracellular concentrations of cytarabinetriphosphate are higher in cytarabine sensitive cells than in resistant cells [109,115]. The retention of cytarabine triphosphate appears to be a critical factor in the response of patients to cytarabine treatment and a correlation between cytarabine triphosphate retention and the duration of complete remission were observed in AML [116]. One of the reasons for giving high-dose cytarabine treatment is to improve the cytarabine triphosphate formation and intracellular cytarabine-triphosphate levels [117]. Increased levels of cytarabine-triphosphate correlate positively with clinical response after high-dose cytarabine treatment [17]; however, Plunkett et al. showed that cytarabine triphosphate formation in leukemic blasts during cytarabine treatment is saturated at plasma levels reached at a dose of 0.5 to $1 \mathrm{~g} / \mathrm{m}^{2}$, which is considerably lower than a standard high dose of $3 \mathrm{~g} / \mathrm{m}^{2}$ cytarabine (see the section on clinical pharmacology) [118].

In addition to its activation to cytarabine triphosphate, cytarabine is converted intracellularly into minor metabolites such as cytarabine diphosphocholine, an analog of the physiologic lipid precursor cytidine diphosphocholine that may interfere in lecithin and sphingomyelins synthesis, and be responsible for neurological toxicities $[119,120]$.

Biological activity of cytarabine depends not only on the intracellular concentrations of cytarabine triphosphate but also on the endogenous nucleotide pools of cytidinetriphosphate (CTP) and dCTP. Cytarabine-triphosphate competes with dCTP for incorporation into DNA and to a lesser extent, with CTP for incorporation into RNA. In particular, high levels of dCTP result in resistance to cytarabine due to competition with cytarabine triphosphate for incorporation into DNA. This mechanism may be attractive for combinational administration of others antimetabolites such as fludarabine and cladribine [121]. Hence, the concentration ratios of cytarabine triphosphate versus dCTP and cytarabine triphosphate vs CTP could be expected as predictive therapeutic efficacy [122]. Beyond the contest for incorporation into DNA, dCTP may affect cytarabine metabolism through feedback inhibition of DCK $[123,124]$ and allosteric activation of CDA enzyme with the subsequent weak phosphorylation and enhanced deamination, respectively [125].

Finally, the intracellular levels of dCTP are regulated by the activities of the cytidine triphosphate synthetase (CTPS), a key enzyme in pyrimidine biosynthesis catalyzing the conversion of uridine triphosphate to CTP, and also modified by ribonucleotide reductase (RR), an enzyme composed of a dimerized large (RRM1) and small (RRM2) subunits catalyzing the reduction in ribonucleotides to deoxyribonucleotides for DNA synthesis $[126,127]$. Activation or inhibition of RR can be directly associated with resistance or sensitivity to cytarabine as tested in a clinical trial [128]. Nucleoside analogs such as fludarabine and cladribine act as inhibitors of RR after intracellular conversion to their deoxynucleotide di- or triphosphate metabolites. Since the inhibition of RR may enhance the cytarabine triphosphate accumulation, the use of agents such as fludarabine and cladribine has been incorporated into therapeutic regimens for AML to potentiate cytarabine metabolism through a sort of biochemical modulation. The same rationale has been applied to enhance cytotoxic activity of cytarabine in lymphocytes of patients with chronic lymphocytic leukemia [129-131]. 


\subsection{Drug Deactivation}

Due to the similarity with the natural precursors required for cellular homeostasis, cytarabine and its metabolites are suitable substrates for various cellular enzymes, which catalyze their conversion into related inactive derivatives. The route of cytarabine inactivation is included in Figure 1.

So, DCK activating function is reversed by cytosolic enzymes belonging to the family of 5'-Nucleotidase (NT5), namely NT5C2 and NT5C3. Opposing dCK, these enzymes catalyze the dephosphorylation of the monophosphate intermediate back to cytarabine through removal of $5^{\prime}$ phosphate $[5,132,133]$.

Also opposing the activation pathway are the two deaminase CDA and deoxycytidine monophosphate deaminase (dCMPD). Cytidine deaminase is a multi-subunit enzyme involved in the maintenance of the pyrimidine nucleotide pool within the cell and physiologically catalyzes the hydrolytic deamination of cytidine to uridine and deoxycytidine to deoxyuridine $[109,134]$. In cytarabine biotransformation, CDA removes the amine group from its cytosine and converts the drug into the inactive uracil arabinoside derivative. Similarly, CMPD deaminates cytarabine-monophosphate to arabinosyl-uracilmonophosphate $[109,134]$. A crucial role for this latter enzyme has been suggested in the metabolism of cytarabine-monophosphate in T-lymphoblastic leukemia [17,87,135-137].

The balance between enzymatic activation and deactivation determines the effective amount of drug converted into the active metabolite cytarabine-triphosphate. This enzymatic balance varies greatly among cell types and maturity. The kinase deaminase ratio averages 0.03 in human AML, whereas the enzyme activities are approximately equal in acute lymphoblastic leukemia and Burkitt lymphoma [109]. Increased levels of CDA are accounted to play a key role in the development of resistance to cytarabine; in contrast, low activity in CDA enzyme can be related to various toxicities [138].

\subsection{Mechanisms of Resistance within the Cytarabine Pathway}

Studying the pathways involved in the transport, activation, or degradation of cytarabine has allowed the identification of mechanisms of resistance. The foregoing considerations over cytarabine metabolism and transport makes it clear that a number of factors could negatively affect response to cytarabine through the reduction in intracellular levels of the cytotoxic triphosphate metabolite of cytarabine. The mechanisms that critically determines resistance to cytarabine appears to be related to a deficiency of cytarabine cellular uptake and retention, overexpression of enzymes inactivating cytarabine, increased cellular dCTP pools, and increased DNA repair. Synoptically, the mechanism of resistance within cytarabine pathway are resumed in Table 4 .

Table 4. Mechanisms of resistance within the cytarabine pathway.

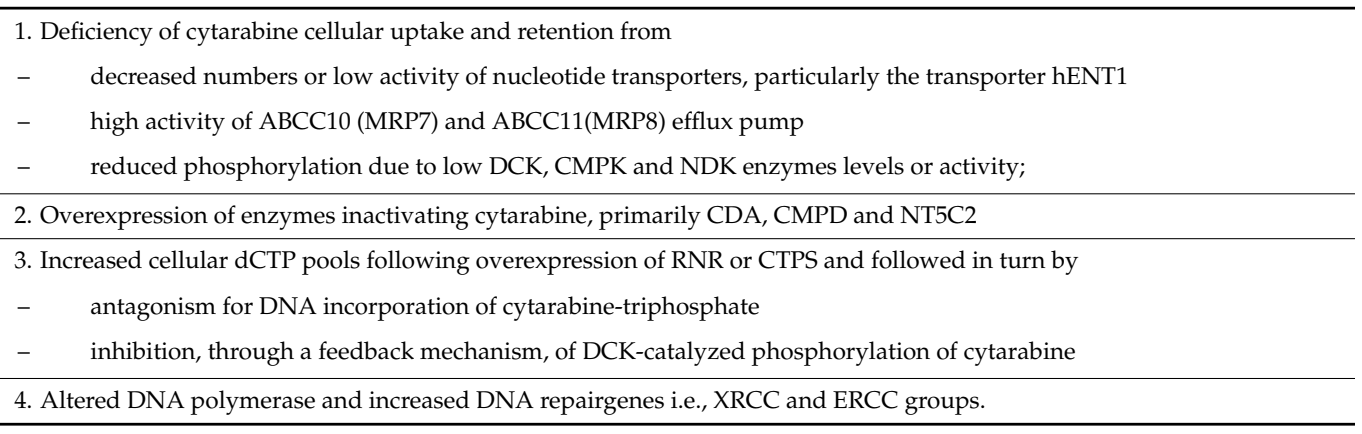

\section{Genetic Determinants of Response and Toxicity to Cytarabine}

\subsection{Old and Novel Approaches to the Discovery of Pharmacogenomics Markers}

The approach to identify genetic variants associated with a cytarabine response phenotype or a serious adverse event was preferentially via a candidate gene or pathway centric approach. Studies on candidate genes have focused on sequence variation, alternative 
splicing and, above all, expression in neoplastic cells of key cytarabine pathway genes, in particular SCL29A1, DCK, CDA, and NT5C2 (Table 5). These studies have unveiled that mRNA expression in these genes is influenced by Single Nucleotide Polymorphisms SNPs in their regulatory regions, while SNPs in coding regions could produce amino acid changes capable to affect the protein or activity of the respective genes $[17,139,140]$.

After the advent of the Human Genome Project together with the avowed completion of the human genome sequence [141] and the genomic characterization [142], the application of molecular technologies to interrogate the entire genome has led to the affirmation of GWA studies and to the discovery of more variants. In less than five years the GWA studies have led to new discoveries about genes and pathways involved in cytarabine metabolism and provided a wealth of new biological insights, and findings of potential clinical utility for prognosis or treatment. An odds ratio of 3.0, or even 2.0 depending on population allele frequencies, would be robust to stratify a population. Odds ratio detected by GWA that are below 1.5 can be frequently be explained by cryptic population stratification, regardless of the $p$ value associated. Such studies have taken into account pharmacodynamic and pharmacokinetic genes, and considered drug response as determined by multiple genes, also out of the drug metabolic pathway, often contributing smaller effects. Differently from candidate gene approach, which started from the patent knowledge of cytarabine biotransformation pathway, and so was hypothesis driven, GWA approach generated new hypotheses and a mess of new data [143]. However, factors such as inadequate sample size, weak genetic effects and overflowing comparisons made using data on SNPs or expression across the genome predispose GWA approach to false positives and upwardly biased effect sizes with large standard errors especially among SNPs with low minor allele frequencies [144].

These shortcomings and the necessity to replicate and validate GWA data into large cohorts of individuals affected by the same neoplasm and receiving the same cytarabineincluding regimen and dose schedule, have prompted researchers in the last years to return to cell-based models [143]. In this respect, the use of human Epstein-Barr virustransformed lymphoblastoid cell lines (LCLs) has progressively developed as a favorable model system [5,154], also owing to the publicly accessibility of panels with genome-wide genotype and gene expression data, including next-generation sequencing (DNA and RNA-Seq) data, for hundreds of established LCLs [155]. The three main collections of LCLs that have been used in pharmacogenomics research on cytarabine are large Centre d'Étude du Polymorphisme Humain (CEPH) pedigrees, Human Variation Panel populations, and International HapMap Project populations [156,157]. Notably, the International HapMap Project has developed a human haplotype map cataloging the common patterns of DNA sequence variation across world populations through additions of SNP genotypes, phased haplotypes, and linkage disequilibrium information, as well as many samples with the complete genome sequenced to capture additionally common and rare variants. All these data have been regularly updated and enlarged over time, and can be accessed and downloaded from the HapMap Project and SNP Consortium Linkage Map Project websites [158-160].

Despite a single-model system cannot signify the complexity of drug effects in the human body, LCLs have the advantages of the easy experimental manipulation and the absence of the in vivo confounders existing in clinical samples. To further enhance evidences from LCLs model and curtail potential in vitro confounders, SNP and gene associations identified within the LCLs model were replicated in relevant tissue and clinical populations. This combined usage of data from both LCLs model and clinical trials has conferred compelling evidence to genotype-phenotype associations and strengthen the findings [155]. Cell models other than LCLs, and including fibroblast cells and peripheral blood mononuclear cells (PBMCs) have also been employed in pharmacogenetic research on cytarabine though with smaller catalogs of lines and accessibility to genetic information. 
Table 5. Overview of gene variants that may affect response to cytarabine.

\begin{tabular}{|c|c|c|c|c|c|c|c|c|c|c|c|}
\hline & \multirow{2}{*}{$\begin{array}{l}\text { GENE } \\
\text { (Protein) }\end{array}$} & \multicolumn{3}{|c|}{ DNA Variants } & \multicolumn{3}{|c|}{ Minor Allele Frequency * } & \multicolumn{2}{|r|}{ Phenotype } & \multirow[b]{2}{*}{ Activities Related SNP } & \multirow[b]{2}{*}{ Ref } \\
\hline & & rs \# & Nucleotide & $\begin{array}{l}\text { Location } \\
\text { (Codon) }\end{array}$ & Afr & Eur & Asn & Clinical & Cell Model & & \\
\hline \multirow{2}{*}{ Transport } & $\begin{array}{l}\text { SLC29A1 } \\
\text { (hENT1) }\end{array}$ & rs747199 & $-706 \mathrm{G}>\mathrm{C}$ & $5^{\prime} \mathrm{UTR}$ & (C) 0 & (C) 0.21 & (C) 0.23 & & $\begin{array}{l}\text { increase in hENT } 1 \mathrm{mRNA} \text { expression in } \\
\text { PBMCs and cytarabine uptake }\end{array}$ & & [145] \\
\hline & $\begin{array}{l}\text { SLC28A3 } \\
\text { (hCNT3) }\end{array}$ & rs11140500 & $\mathrm{T}>\mathrm{C}$ & $5^{\prime} \mathrm{UTR}$ & $\begin{array}{l}(\mathrm{T}) \\
0\end{array}$ & $\begin{array}{l}(\mathrm{T}) \\
0.01 \\
\end{array}$ & $\begin{array}{r}(\mathrm{T}) \\
0.29 \\
\end{array}$ & & & & [96] \\
\hline \multirow{5}{*}{ Activation } & \multirow{3}{*}{$\begin{array}{l}D C K \\
\text { (DCK) }\end{array}$} & $\begin{array}{l}\mathrm{NA} / \\
\mathrm{rs} 2306744\end{array}$ & $\begin{array}{l}-360 \mathrm{C}>\mathrm{G} / \\
-201 \mathrm{C}>\mathrm{T}\end{array}$ & $5^{\prime} \mathrm{UTR}$ & NA & NA & NA & $\begin{array}{c}\text { mRNA expression } \\
\text {-360GG/-201TT } \\
\text { haplotype shown good } \\
\text { clinical response in AML }\end{array}$ & $\begin{array}{l}\text { altered enzyme kinetics, increased } \\
\text { cytarabine triphosphate intracellular } \\
\text { concentrations }\end{array}$ & & [146] \\
\hline & & rs66878317 & $70 \mathrm{~A}>\mathrm{G}$ & $\begin{array}{c}\text { Exon } 1 \\
\text { (Ile24Val) } \\
\end{array}$ & (G) 0 & (G) 0 & (G) 0.03 & & Altered substrate kinetics & & [147] \\
\hline & & rs67437265 & $364 \mathrm{C}>\mathrm{T}$ & $\begin{array}{c}\text { Exon } 3 \\
\text { (Pro122Ser) }\end{array}$ & (T) 0.06 & (T) 0.01 & (T) 0.04 & & $\begin{array}{l}\text { variant Pro122 shown lower } \\
\text { enzyme activity }\end{array}$ & & [147] \\
\hline & $\begin{array}{l}\text { NDK- } \\
\text { NME1 } \\
\text { (NDK) }\end{array}$ & rs2302254 & $835 \mathrm{C}>\mathrm{T}$ & $5^{\prime} \mathrm{UTR}$ & (T) 0.37 & (T) 0.18 & (T) 0.25 & $\begin{array}{l}-835 \mathrm{~T} / \mathrm{T} \text { increased risk } \\
\text { of neurotoxicity. }\end{array}$ & & & [148] \\
\hline & $\begin{array}{l}\text { RRM1 } \\
\text { (RRM1) }\end{array}$ & rs1561876 & $-2993 \mathrm{~A}>\mathrm{G}$ & $3^{\prime} \mathrm{UTR}$ & (G) 0.72 & (G) 0.12 & (G) 0.21 & $\begin{array}{l}\text { cytarabine triphosphate } \\
\text { levels Increased, response } \\
\text { and survival improved }\end{array}$ & & & [149] \\
\hline \multirow{6}{*}{ Deactivation } & \multirow{4}{*}{$\begin{array}{l}C D A \\
\text { (CDA) }\end{array}$} & rs602950 & $-92 \mathrm{~A}>\mathrm{G}$ & $5^{\prime} \mathrm{UTR}$ & (G) 0.07 & (G) 0.32 & (G) 0.13 & & \multirow{2}{*}{$\begin{array}{l}\text { PBMC from healthy donors, report that } \\
\text { among individuals carrying two * } 2 A \\
\text { alleles (seeTable } 1 \text { ), cytarabine-induced } \\
\text { toxicity was approximately } 53 \% \text { higher } \\
\text { whencompared with carriers of no }{ }^{*} 2 A \\
\text { alleles and nearly } 74 \% \text { higher compared } \\
\text { with carries of two wild-type * } 1 A \text { alleles. }\end{array}$} & \multirow{2}{*}{$\begin{array}{l}\text { Low mRNA level. High } \\
\text { level of cytarabine } \\
\text { triphosphate resulting } \\
\text { in bone marrow } \\
\text { depression }\end{array}$} & \multirow[t]{2}{*}{ [16] } \\
\hline & & rs3215400 & -31Del C & $5^{\prime} \mathrm{UTR}$ & (C) 0.33 & (C) 0.43 & (C) 0.44 & $\begin{array}{l}\text { del/del shown } 1.37 \text { fold } \\
\text { increased expression than } \\
\text { ins C/insC Parmar }\end{array}$ & & & \\
\hline & & rs2072671 & $79 \mathrm{~A}>\mathrm{C}$ & $\begin{array}{c}\text { Exon } 1 \\
\text { (Lys27Gln) }\end{array}$ & (C) 0.08 & (C) 0.33 & (C) 0.13 & $\begin{array}{l}\text { Low enzyme activity in } \\
\text { Lys27Lys than Gln27Gln }\end{array}$ & $\begin{array}{l}\text { Cytidine is the } 2.4 \text { fold lower } \mathrm{K}_{\mathrm{m}} \text { for } \\
\text { Lys27Lys than Gln27Gln in European }\end{array}$ & & \multirow[b]{2}{*}{150} \\
\hline & & rs1048977 & $435 \mathrm{~T}>\mathrm{C}$ & $\begin{array}{c}\text { Exon } 4 \\
\text { (Thr145Thr) }\end{array}$ & (T) 0.37 & (T) 0.33 & (T) 0.25 & $\begin{array}{c}\text { Haplotype CDA } \\
\text { *2A(435A) display higher } \\
\text { CDA activity compared } \\
\text { with others }\end{array}$ & & & \\
\hline & $\begin{array}{l}N T 5 C 2 \\
(\text { NT5C2) }\end{array}$ & rs11598702 & $175+1178 \mathrm{~A}>\mathrm{G}$ & $5^{\prime} \mathrm{UTR}$ & (C) 0.19 & (C) 0.35 & (C) 0.22 & $\begin{array}{l}\text { Low mRNA expression } \\
\text { and cytarabine sensitivity } \\
\text { in cells derived from } \\
\text { AML patients }\end{array}$ & $\begin{array}{l}\text { Low mRNA DFS } 17.5 \text { months vs } 11 \\
\text { months in AML }\end{array}$ & Low enzyme activity & [151] \\
\hline & $\begin{array}{l}N T 5 C 3 \\
\text { (NT5C3) }\end{array}$ & rs3750117 & $276 \mathrm{~T}>\mathrm{C}$ & Tyr92Tyr & (T) 0.17 & (T) 0.29 & (T) 0.5 & & $\begin{array}{l}\text { In PBMCs haplotypes T276/H283 and } \\
\text { T276/C306 decreased enzyme activity }\end{array}$ & & [152] \\
\hline
\end{tabular}


Table 5. Cont.

\begin{tabular}{|c|c|c|c|c|c|c|c|c|c|c|c|}
\hline & \multirow{2}{*}{$\begin{array}{c}\text { GENE } \\
\text { (Protein) }\end{array}$} & \multicolumn{3}{|c|}{ DNA Variants } & \multicolumn{3}{|c|}{ Minor Allele Frequency * } & \multicolumn{2}{|c|}{ Phenotype } & \multirow[b]{2}{*}{ Activities Related SNP } & \multirow[b]{2}{*}{ Ref. } \\
\hline & & rs \# & Nucleotide & $\begin{array}{l}\text { Location } \\
\text { (Codon) }\end{array}$ & Afr & Eur & Asn & Clinical & Cell Model & & \\
\hline \multirow{2}{*}{ DNA repair } & $\begin{array}{c}\text { XRCC1 } \\
\left(\mathrm{XR} \_\right)\end{array}$ & rs 25487 & $28152 \mathrm{G}>\mathrm{A}$ & $\begin{array}{c}\text { Exon } \\
\text { (Arg399Gln) }\end{array}$ & (T) 0.12 & (T) 0.35 & (T) 0.25 & \multirow{2}{*}{$\begin{array}{l}\text { Mutations are correlated } \\
\text { to prediction of better } \\
\text { treatment outcomes in } \\
\text { patients with AML }\end{array}$} & & $\begin{array}{l}\text { Low activity in Base } \\
\text { excision DNA repair }\end{array}$ & [153] \\
\hline & $\begin{array}{l}E R C C 2 \\
\text { (XDP) }\end{array}$ & rs 13181 & $35931 \mathrm{~A}>\mathrm{C}$ & $\begin{array}{c}\text { Exon } \\
\text { (Lys751Gln) }\end{array}$ & (G) 0.21 & (G) 0.38 & (G) 0.09 & & & $\begin{array}{l}\text { Low activity in } \\
\text { Nucleotide excision } \\
\text { DNA repair }\end{array}$ & [153] \\
\hline
\end{tabular}

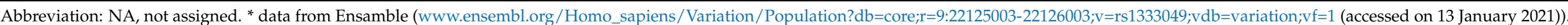
\# genetic locus. 
Cell lines have also been used for functional validation by means of silencing RNAmediated gene silencing and recombinant protein expression strategies, discoveries from GWA studies that may have resulted in some false positives [5,150,152].

LCLs have been applied successfully also to the study of genetic regulation of gene expression within the causal pathway between genetic variants and the complex phenotypes of toxicity and efficacy. The genomic regions regulating quantitative expression differences, or expression quantitative trait loci (eQTL), have been mapped using 14 CEPH pedigrees and found that gene expression is heritable [161]. Expression levels across the genome can be examined through microarray technology simultaneously, and eQTL studies can integrate genetics and pharmacologic phenotypes, as in the so called 'triangle method'. After its first presentation in 2007 [162], this type of GWA approach has been effectively adopted to identify novel genetic variants able to predict sensitivity to cytarabine, as well as a variety of chemotherapeutics, including etoposide, cisplatin, carboplatin, and daunorubicin. It develops through the three different arms of (1) preliminary evaluation of relevant associations significant between SNPs and sensitivity to the drug, (2) eQTL analysis performed from this list of SNPs to discover the subset of SNPs linked to the expression of transcripts, (3) assessment of the expression of the list of target genes for significant linear correlation to drug sensitivity. It has been used to compare the pharmacogenomics of cytarabine susceptibility between the HapMap Phase I/II CEU and YRI populations and to explore in LCLs from 60 CA, 54 AA, and 60 HCA individuals of the Human Variation Panel the pharmacogenomics of cytarabine and that of the congener chemotherapeutic agent gemcitabine [98,163]. Population-specific pharmacogenetic signatures consisting of four SNPs clarifying $51 \%$ of the variability in cytarabine cytotoxicity were identified among CEU, as well as five SNPs explaining 58\% of the variation among the YRI [163].

The results from these studies on cytarabine and from other LCL-based pharmacogenomics research, are contained within the Pharmacogenomics, And Cell database (PACdb, www.pacdb.org (accessed on 13 January 2021)) which provides a unique resource to the researchers [164]. Investigators can look for specific genes and SNPs of interest to determine if they have been found to associate with a particular drug phenotype. At present, PACdb contains summary results for SNP genotype versus cytotoxicity and gene expression versus cytotoxicity for daunorubicin, etoposide, cisplatin, carboplatin, and cytarabine. PACdb also enfolds population-differential expression data and splicing-index data.

Beyond GWA studies, different data generation techniques can be used, depending on the scientific questions and hypothesis under testing. Therefore, if it is assumed that rare, coding variants will be most relevant for the pharmacogenomics trait of interest, exosome sequencing or exome chips would be the most likely methodology chosen. On the contrary, if gene expression variation from eQTL or epigenetic variation are conjectured to be most important, next generation sites (methyl-seq) may be selected instead.

Hereafter, we run through studies addressing genetic variants, polymorphisms, enzyme activities and protein expression levels associated to cytarabine. These are also recapped in Table 4, together with their associated phenotypes.

\subsection{Drug Uptake/Efflux}

\subsubsection{Genetic Variants of Cytarabine Transporters}

Cytarabine is typically hydrophilic and, unless given at high dose, requires nucleoside transporter proteins to uptake efficiently inside the cells. At conventional doses of $100-200 \mathrm{mg} / \mathrm{m}^{2}$ of cytarabine, hENT1 is accounted for up to $80 \%$ of cytarabine inward transport though considerable interpatient variations have been observed [165]. hENT1 (SLC29A1) coding region appears to be highly conserved and, at functional characterization, genetic variants do not contribute to inter-individual differences in response to nucleoside analog drugs [166,167]. In contrast, in the hENT1 5'UTRpromoter region three out of four naturally occurring haplotypes of three polymorphisms $(-1345 C>G,-1050 G>A$, and $706 \mathrm{G}>\mathrm{C}$ ) were associated with higher mRNA expression [145]. Since no functional coding SNPs seem to modulate the function of hENT1 while the variability in expression 
of hENT1 is reported to affect sensitivity to cytarabine, a possible role of interacting transcription factors may be contributive. So, any genetic variation in the hENT1 locus that may disrupt or create binding sites for Hif-1 and other transcription factors could eventually alter hENT1 expression as well as activation of PPAR $\alpha[103,104]$. Indeed, 30 novel polymorphisms in both coding and in the region of promoter were identified in SLC29A1 from Japanese subjects; yet the functional significance of these variants remains to be defined [168].

The hENT1 transporter was highly up regulated in biphenotypic leukemia associated with the 11q23 MLL gene $(4 ; 11)$ translocation [169].

Inter-temporal marks variability of hENT1 staining intensities was documented in the Reed-Sternberg cells of Hodgkin lymphoma using immunohistochemistry applied to frozen tissues [170]. Immunochemistry assays for hENT1 was correlated with clinical outcome in CALGB 59804 multicenter trial in Hodgkin lymphoma treated with the cytarabine congener gemcitabine; in this study, the opposite of the logical expected result was found since patients with high hENT expression had a lower likelihood of response and failure-free survival [171,172].

In a study conducted in 115 non-Hodgkin lymphoma patients, a relatively high frequency of hENT1 protein positivity (i.e., immunostaining in $>50 \%$ of neoplastic cells) was found in malignant follicular center cells and in particular in Burkitt Lymphoma (63\%), diffuse large B-cell lymphoma (DLCL; 45\%), and follicular lymphoma (40\%) [173].

The application of GWA studies to samples from European AML adult patients identified the SNP (rs11140500) in SLC28A3 for hCNT3 as of clinical relevance [96].

Consistent with the process of an efflux pump and contributive to cytarabine drug resistance, the expression of the ABC transporter ABCC10 (MRP7) in HEK293 cells reduced the accumulation of cytarabine [100] while ABCC11 (MRP8) determined increased cellular efflux of phosphorylated cytarabine metabolites [174].

\subsubsection{Transporters and Response and Toxicity to Cytarabine}

There is a substantial clinical evidence indicating that the efficiency of intracellular cytarabine concentration mediated by hENT1 membrane facilitating diffuser is related to clinical outcome [102].

The cell surface abundance of nucleoside transporter sites is closely correlated to cytotoxicity of cytarabine [101], and a threshold level of hENT1 protein expression is necessary to make cancer cells sensitive to cytarabine [95].

The reduction in hENT1 expression was a common mechanism for resistance to antimetabolite treatment $[175,176]$ and represents a major factor in cytarabine resistance in leukemic blasts of childhood AML [106]. Among 77 AML patients, those presenting hENT1 deficiency at diagnosis had significant worse disease-free survival and overall survival [107]. A high sensitivity to cytarabine, found in children affected by gene rearranged biphenotypic acute lymphoblastic leukemia, has been attributed to highly upregulation of the hENT1 transporter [169].

A study using a cytarabine resistant CCRF-CEM cell line reported that genetic mutations of hENT1 that alter mRNA splicing and protein translation provide mechanisms for resistance to drug treatment [177]. Additional investigation on the genetic basis for the cytarabine resistance of CCRF-CEM leukemia cells led to the discovery of missense mutations in critical amino acids for hENT1 nucleoside recognition and uptake [178].

There is no clear functional impact of the genetic variant in the promoter region of $h E N T 1$ gene, $(-706 \mathrm{G}>\mathrm{C})$. Some authors reported, anonymously, a statistically significant tendency towards higher mRNA levels in PBMCs from individuals heterozygous for this variant, as compared with wild-type carriers [145]. Others did not find any impact on toxicity and suggest a small part of hENT1 genetic variations in the modulation of cytarabine toxicity in normal blood cells [16]. These latter results are in line with the findings from GWA studies on LCLs [98]. 
Of significant practical implication is the fact that hENT1 is strongly inhibited by various receptor tyrosine kinase inhibitors, an interaction that could limit cytarabine use with targeted drugs [179,180].

Several studies have shown that the nucleoside transporter hCNT3 is involved in cytarabine cytotoxicity and resistance $[95,97]$. The SNP (rs11140500) in SLC28A3 for hCNT3 was recently found to be associated with disease-free survival at multivariate analysis among 154 European AML adult patients on high-dose cytarabine [96]. However, since this SNP represents an uncommon variant, any correlation with clinical and survival data should more properly rely on additional functional studies or replication in larger sample size.

No significant gene polymorphisms have been associated with resistance to cytarabine for ABC transporters, though for ABCC11 gene SNP (538G>A) has been suggested to be a clinical biomarker for prediction of chemotherapeutic efficacy in breast cancer [181] and SNP (G>A, T546M) predictive for 5-fluorouracil-induced severe toxicity [182].

Recently, a differential expression of $A B C C 11$ (MRP8) mRNA has been demonstrated in AML blasts from 50 patients, together with a low probability of overall survival at 4 years for those with high expression of MRP8. The result was statistically significant at regression analysis and independent of the dosage of cytarabine delivered during antileukemic treatment [99].

\section{Drug Activation}

\subsection{Genetic Variants of Kinases}

Among the kinases participating to the multistep activity that lead to phosphorylation of cytarabine up to its triphosphate active metabolite, DCK is the rate-limiting enzyme. It exerts highest activity during the $S$ phase of the cell cycle and is strongly inhibited by the physiological dCTP substrate [183].

The gene coding for DCK and a mutated version found in cytarabine resistant cells have been cloned $[177,184]$. The DCK gene is fairly conserved in Caucasians, in contrast to African populations [146] where higher level of DCK mRNA expression has been demonstrated [147]. This may explain, to some extent, population differences observed in the grade of sensitivity to cytarabine since higher DCK expression could lead to increase intracellular cytarabine triphosphate resulting in increased cellular sensitivity. The activity and expression of $D C K$ varies widely in normal and malignant cells; furthermore, there is a 50-fold variation in DCK mRNA expression in patient leukemic cells, a 35-fold variation in DCK mRNA in primary AML cells, a 36-fold change in liver tissue and a 150-fold change in human liver metastases of colorectal cancer origin [185].

Several genetic variants in the $D C K$ gene have been evidenced: five regulatory mRNA expression SNPs $(-125 \mathrm{G}>\mathrm{T},-201 \mathrm{C}>\mathrm{T},-289 \mathrm{~T}>\mathrm{A},-360 \mathrm{C}>\mathrm{G}$, and $-740 \mathrm{G}>\mathrm{C})$ and three non-synonymous coding changes Ile24Val, Ala119Gly, and Pro122Ser [147].

The second phosphorylating enzyme, CMPK, is found in more than a hundredfold higher concentration than DCK. Its affinity for cytarabine-monophosphate is low but greater than the affinity for the competitive physiologic substrate deoxycytidinemonophosphate. Because of its relatively poor affinity for cytarabine-monophosphate, this enzyme could become rate limiting at low cytarabine-monophosphate concentrations [109]. No major polymorphism in CMPK enzyme with clinical application has been identified.

The third phosphorylating enzyme, NDK, appears not to be rate limiting because it is present in very high concentration [109]. In total, five SNPs within the NME1 gene coding for NDK have been found in a retrospective study on 360 Caucasian patients suffering from AML [148].

\subsection{Kinases and Response and Toxicity to Cytarabine}

Clinical studies have shown that low intracellular concentrations of the chemotherapeutic cytarabine in leukemia cells predict poorer outcome to treatment $[186,187]$. Likewise, 
low mRNA levels of DCK in blast cells predict shorter disease free survival, as well as overall survival in an AML population treated with cytarabine [188]. Ex vivo models using LCLs were able to associate these two observations to SNPs in DCK. Examination of LCLs from HapMap populations determined that SNPs within DCK resulted in altered enzyme kinetics, increased cytarabine triphosphate intracellular concentrations, higher basal levels of DCK, and increased sensitivity to cytarabine [147,163]. Additional SNPs in the 3_untranslated region of DCK (positions_36113 and _35708) were also associated with DCK basal expression and cytarabine sensitivity in the HapMap cell lines and cytarabine triphosphate levels in leukemic cell samples from patients with AML, respectively [147,163]. Thus, for cytarabine pharmacogenomics, clinical studies were successful in identifying a biomarker (cytarabine triphosphate levels), and candidate gene (DCK), whereas cellbased models identified candidate SNPs associated with these phenotypes that could be potentially useful in clinical dosing algorithms.

The two regulatory SNPs (-360C and -201C) have been in linkage disequilibrium, and have been associated with a more favorable 2 years disease free survival in 122 AML Asian patients, and this was explained by lower DCK mRNA expression leading to reduced transcriptional activation when compared with the -360C / -201C haplotype [189]. These polymorphisms have low frequency in Caucasian population [190]. A reduced enzyme activity in DCK 122Ser (rs6743726) reported as being $43 \pm 4 \%$ of the wild type (WT) allele in vitro in DCK coding region [168]. Some authors have found this association to be statistically significant, while others have failed to find it $[147,191]$; anyway, more recently this polymorphism has been associated with a reduction in enzyme activity as compared with WT that reached statistical significance [192].

In total, five SNPs within the NDK gene promoter have been correlated with druginduced toxicity, in Caucasian AML patients. No significant correlation between SNPs and disease-free survival or OS has been found, but significant correlation with low platelet count has been identified for the NDK promoter SNP-835 C/T (rs2302254). In addition, increased risk of neurotoxicity for the SNP-835 C/T for allele T/T has been identified also at multivariate analyses [148].

\subsection{Genetic Variants of Ribonucleotide Reductase and Cytidine 5'-Triphosphate Synthetase}

Another family of 'activators' could be represented by RRM1 and RRM2 catalyzing the reduction in ribonucleotides to their corresponding deoxy-ribonucleotides. Diphosporilated cytarabine influence indirectly pharmacokinetics by inhibition of ribonucleotide reductase (RRM1, RRM2, and RRM2B) enzymes that catalyze reactions which generate deoxynucleoside triphosphates required for DNA synthesis.

Low levels of deoxycytidine triphosphate due to CTPS inhibition or inhibition of ribonucleotide reductase lead to Ara-C phosphorylation (by reducing feedback inhibition of DCK), as well as incorporation of Ara-CTP into DNA. Conversely, cytarabine-triphosphate exerts only a weak inhibition and this lack of feedback allows accumulation of the cytarabine nucleoside to a higher concentration [17].

Inhibition of CTPS with cyclopentenyl cytosine has been shown to deplete CTP and dCTP pools and increased sensitivity to cytarabine in human T-cell lymphoblastic cell lines and myeloid leukemia cell lines [126,193,194]. Furthermore, the dNTPase SAMHD1, which regulates dNTP homoeostasis antagonistically to ribonucleotide reductase (RNR), limits Ara-C efficacy by hydrolyzing the active triphosphate metabolite Ara-CTP. Thus, targeting SAMHD1 to enhance Ara-C efficacy is a rational strategy to improve survival in AML and other hematological malignancies [195].

\subsection{Ribonucleotide Reductase, Cytidine 5'-Triphosphate Synthetase and Response and Toxicity to Cytarabine}

Ribonucleotide reductase regulates dCTP and other deoxyribonucleotides levels inside the cells so that its activity is straightly associated to sensitivity or resistance to cytarabine. Inhibition of RR can culminate in the accumulation of cytarabine triphosphate [127]. 
Biochemical modulation of cytarabine by nucleoside analogs such as fludarabine and cladribine has been shown to be feasible in adult and pediatric leukemia patients as they stimulate the cytarabine triphosphate accumulation by the inhibition of RR $[129,196,197]$.

SNPs within the RRM1 and RRM2 genes were evaluated in the HapMap LCLs from CEU and YRI panels to find possible correlation with expression and cytarabine chemosensitivity. SNPs of expected importance were further evaluated in leukemic blasts from 276 AML patients. RRM1 SNP rs1042919 (which occurs in linkage disequilibrium with various other SNPs) and promoter SNP rs1561876 were related to intracellular cytarabine triphosphate levels, response after up front treatment, disease and overall survival [149].

Consistent with previous studies showing that SNPs in RRM1 are associated with response or toxicity to gemcitabine-based chemotherapy in lung and breast cancer patients $[198,199]$; findings from a recent study conducted with GWA studies in 154 European and 125 non-European AML adult patients suggest that the SNPs in RRM1 are associated with AML response to chemotherapy that include cytarabine [96]. These results suggest that SNPs within RR retain clinical significance and might represent useful predictive markers of response to cytarabine deserving further validation in larger cohorts.

As regards CTPS, mutations have been identified within the coding region in cytarabine resistant strains of Chinese hamster ovary cells, but none of these mutations was identified in samples from 36 patients, with acute leukemia refractoriness or recurrence $[200,201]$. Thus, mutations in these sites within the human CTPS gene do not performance a primary mechanism of resistance to cytarabine. In the International HapMap Project database, several SNPs are indicated, and two synonymous SNPs, Gln167Gln and Val500Val were observed with the allele frequency of 0.28 and 0.25 , respectively. Future efforts will address the clinical relevance of these findings.

\section{Drug Deactivation}

\subsection{Genetic Variants of Deaminases and $5^{\prime}$-Nucleotidases}

Cytarabine catabolism is performed through processes of deamination, involving CDA and CMPD enzymes, and dephosphorylation by NT5C family enzymes.

The primary role in cytarabine degradation and detoxification is played by CDA.

In total, three important variants in the $5^{\prime}$ UTR promoter region of $C D A$ gene $(-451 \mathrm{C}>\mathrm{T}$, $-92 \mathrm{~A}>\mathrm{G}$, and del-31) were associated to alterations in putative transcription factor binding sites and impacted CDA enzyme activity as assayed in peripheral blood mononuclear cells (PBMCs) of healthy individuals [202]. Of particular relevance is the CDA nucleotide variant 79A $>C$ which leads to a non-synonymous amino acid substitution in exon 1 from a Lysine to a Glutamine (Lys27Gln) and results in decreased activity of CDA with a 30\% reduction in the cytarabine deamination rate [203]. The nucleotide 79A $>\mathrm{C}$ is prevalent in all of the population groups studied, with a $20 \%$ frequency of the variant allele in the Japanese and $36 \%$ in the European population [204]. The expression of this CDA Gln variant has been subsequently assayed through an haplotype analysis in an ethnically diverse sample set [188]. In this study, the silent variant 435C $>\mathrm{T}$ (Tyr145Tyr) was reported as frequent and so proposed for integrating the coding variant Lys27Gln and the three promoter variants, $-451 \mathrm{C}>\mathrm{T}-92 \mathrm{~A}>\mathrm{G}$, and $-31 \mathrm{del}$, to define, finally, 15 different haplotypes having a frequency $>1 \%$ among Caucasian population. This set of haplotypes encompasses a wide array of genotypically characterized profiles of toxicity ranging from $C D A^{*} 1 A$ to $C D A^{*} 2 A$, this latter constituted by a combination of variant alleles $-451 \mathrm{~T},-92 \mathrm{G},-31 \mathrm{Del}$, and $79 \mathrm{C}(27 \mathrm{Gln})$, having the least and the most severe toxicities, respectively (Supplemental Table S1) [205]. Recently, a CDA protein-stability study based on site-directed mutagenesis showed low catalytic efficiency in the Gln27/Tyr70 variation, toward other haplotypes. These results confirm that patients carrying the mutant variant Tyr70 (208AA) may have a greater toxic exposure to cytarabine based therapy [206]. However, homozygous CDA Tyr70 variants very low frequent in Caucasian population [150].

Lately, beyond these recognized variants in CDA gene, other intronic polymorphisms were identified as involved in low enzyme efficiency in Asian populations. Among these 
the SNP 235-209T>C, detected in intron 3 at a frequency of 0.06 , has value in pharmacogenomics [207].

CMPD deaminates cytarabine-monophosphate to arabinosyl uracil-monophosphate. Genomic screening of coding regions and the proximal promoter of CMPD in Caucasian and African ethnic groups identified a non-synonymous SNP 172A $>$ G (Asn58Asp) with a significant loss of activity in vitro assays [205].

Functional genomics studies in NT5C2 have been identified over 41 SNPs by GWA studies on ethnically well-defined DNA. Poor mRNA expression was detected in the presence of C>T rs11598702 in NT5C2; in addition, this SNP occurred in linkage disequilibrium with rs1163238 and 11191612, two further SNPs located in 5' UTR [151]. The real clinical relevance of these genetic polymorphisms is to be established. Among NT5C3 polymorphisms, the association of synonymous Tyr92Tyr (nucleotide 276T) and non-synonymous His283Asp is correlated with decreased level of enzyme activity. These findings suggest that a genetic variation in NT5C3 gene may influence drug response [152].

\subsection{Deaminases, 5'-Nucleotidases and Response and Toxicity to Cytarabine}

There have been several studies focusing on the influential effect of generic polymorphisms in the CDA genes on cytarabine pharmacokinetics and pharmacodynamics. Patients with impaired CDA activity might develop strong toxicities after administration of cytarabine while CDA overexpression in tumor tissues might reduce the antitumor efficacy of the drug [134]. The most significant influence between subject variability and toxicity has been observed in "poor metabolizer" $C D A^{*} 2 A$ and *2B variants (Supplemental Table S1). In patients with $A M L$, elevated levels of CDA have been directly correlated with relapse and lower levels of CDA with prolonged remission [203,208].

A study performed on native PBMCs from 100 healthy volunteers reported a cytarabineinduced toxicity of approximately $53 \%$ among individuals carrying two ${ }^{*} 2 A$ alleles that are higher than carriers of no ${ }^{*} 2 A$ alleles and nearly $74 \%$ higher than carriers of two wildtype ${ }^{*} 1 A$ alleles [16]. The most important association has been observed for $C D A-31 D e l$, where the CDA mRNA expression has been 1.37-fold increased among homozygote carriers of the deletion compared with wild type carriers (no deletion-31) [16].

CDA enzyme deficiency may occur in poor metabolizers patients carrying homozygous CDA 79C allele as assessed by different studies [10]. An increase in post induction treatment-related mortality for the $\mathrm{C}$ allele of the $79 \mathrm{~A}>\mathrm{C}$ variant has been reported among 457 children with AML receiving cytarabine within Children's Cancer Group 2941 and 2961 protocols [209]. The rate of post-induction treatment-related death was 2.5-fold higher in the 79CC group as compared with children with two wild-type alleles [209]. Differently, a lower incidence of grade III and IV liver toxicity was recorded within the multicenter trial AML96 of the German Study Initiative Leukemia among patients carrying the wild-type alleles of the 79AA [191]. In this study polymorphism, -451TT was found as an additional single $C D A$ variant of clinical prognostic relevance among the 360 AML adult patients receiving cytarabine, was associated with risk for death $>50 \%$ as compared with wild-type carriers and maintained independent prognostic value also in multivariate analysis [191].

In both studies, only the influence of single $C D A$ variants has been studied and no haplotype analysis has been performed.

The role of CMPD in the pathogenesis of toxicity of cytarabine, has been poorly defined differently from the congener analog gemcitabine whose enzymatic deamination activity is impaired in the presence of the SNP 172A>G (Asn58Asp) with consequent toxicity due to reduced clearance of monophosphorylated metabolites [205].

Since monophosphorilated intermediate of cytarabine activation is reduced by cytosolic 5'-nucleotidases NT5C2 and NT5C3, the activity level of this enzyme may represent one of the factors affecting the clinical outcome of cytarabine therapy. Increased expression of NT5C2 has been correlated with resistance to cytarabine chemotherapy and to a lower survival rate in a hundred patients undergoing cytarabine chemotherapy [210]. 
An increase in the NT5C2 has emerged as a mechanism of resistance to cytarabine. Patients with AML and low expression level of NT5C2 have a better overall survival after treatment with cytarabine than patients with high expression [211]. NT5C2 is implicated in pharmacokinetic of cytarabine has been associated with poor clinical outcome [151].

Further evidences for the implication of NT5C2 in the cellular response to cytarabine came from the correlation between the formation of cytarabine triphosphate in blasts from patients with AML and their corresponding ratio of the expressions of DCK and NT5C2 [212]. In a recent genetic association study of disease free survival in 154 AML patients of European ancestry, five SNPs in the NT5C2 region were predictive [96]. The aforementioned data have prompted a search for NT5C2 inhibitors whose structural optimization is currently ongoing [213]. High NT5C3 expression was found to be associated with better outcome for AML patients receiving cytarabine [210].

\section{Drug Damage Repair}

\subsection{Genetic Variants in DNA Repair Genes}

Pharmacogenomic studies in cancer cells have consistently shown increased activity of nuclear protein able to remove alien nucleotides from DNA [214]. DNA Repair mechanism is controlled essentially by the Base Excision Repair (BER) and Nucleotide Excision repair (NER) genes family; furthermore genetic variants in any of these genes may modulate repair capacity and contribute to individual variation in chemotherapy response. Primary genes involved in DNA adduct restoration are the X-ray Cross-Complementing group (XRCC) and Excision Repair Cross-Complementing group (ERCC, also named XPD). In addition, other genes as ATM, RAD51, and BRCA1 are described to be involved in resistance to nucleosides analog [215].

\subsubsection{DNA Repair Genes and Response and Toxicity to Cytarabine}

Germline variation in DNA repair gene encoding XRCC1 codon Arg399Gln variants has been associated to decrease in risk of toxicity in cancer [216]. In addition, two variants in ERCC2 codon Lys751Gln and Asp312Gln were associated with better treatment outcomes in patients with AML receiving cytarabine based-therapy [153]. In a study of 307 AML adult an increased risk of relapse was associated to heterozygosis phenotype for Lys751Gln [217].

\subsection{2. 'Out of Pathway' Genes}

Even if the genes or enzymes pathways which control cytarabine mechanism are known, these may or may not explain variation in response. So, while this knowledge has guided the initial molecular assays, subsequently, with the high-density genotype data available for the HapMap samples the application of genome-wide genotyping and wholegenome sequencing have led to the discovery of genes out of pathway showing correlation with phenotypes of toxicity and response to cytarabine, and representing potential novel pharmacogenomics markers.

Associations between the expression of two genes (GIT1 and SLC25A37) and cytarabine were validated in an additional panel of LCLs.

GIT1 acts as a scaffold for certain intracellular signaling cascade proteins, including the MAP kinase pathway. Increased GIT1 expression has been shown to increase MAP kinase signaling [218,219], which may result in increased apoptosis in response to cytarabine [163].

SLC25A37 is a member of the SLC25 solute carrier family. This carrier imports iron into mitochondria and is involved in heme biosynthesis [220]. Interestingly, intracellular iron concentration has been shown to be related to cytarabine cytotoxicity. In a study of leukemia cell lines, exposure to desferrioxamine and therefore depletion of intracellular iron resulted in increased sensitivity to cytarabine [221].

This is also the case of genetic variation in FKBP5 gene, a candidate gene outside the metabolic nucleoside analogue pathway whose down regulation showed reduced sensibility to cytarabine in two hundred ethnically defined Human Variation Panel lymphoblastoid 
cell [5]. The SNPs rs3798346 and rs7755289 in FKBP5 gene were associated with statistically significant worse survival in 187 pediatric AML patients [222].

Decreased expression of RAD51, would result in weakened repair of DNA double strand breaks induced by cytarabine triphosphate, thus reducing cell survival [223]. This mechanism has prompted the use of HDACIs sine these agents suppress the transcript and protein levels of the transcription factor gene E2F1, a key factor for RAD51 expression [223].

Recently, a GWA based study, involving 523 LCLs, identified several statistically significant SNPs in Mutated Colorectal Cancer (MCC) gene associated with cytarabine sensitivity. In particular, one of them the rs1203633 with AA genotype was linked with poorer OS $(p=0.015)$ in AML patients of multicenter AML02 trial.

\section{Consistency and Applicability of Pharmacogenomic Studies on Cytarabine}

Candidate gene approaches and GWA studies have found out some subsets of patients more likely to benefit from cytarabine-inclusive treatment or those more likely to experience adverse events. In particular, the expression levels or genetic polymorphisms of genes within the cytarabine biotransformation pathway including SLC29A1, DCK, CDA, RRM1, NT5C2 has appeared promising predictors of prognosis or toxicity to this drug.

However, translating laboratory findings into the clinic has been painfully slow and the real contribution of genetic variation of these candidate genes to exposure and response to cytarabine is overall unsettled despite differences in outcomes and toxicities emerged from clinical trials [224-226]. Ideally, in both candidate gene and GWA studies, patients will have been treated within a single-agent study and not a combination one, so to attribute properly phenotypic effects or absence of an effect. Moreover, when associations between genetic polymorphisms and drug concentrations, response, or toxicity were detected, a replication study was required. Accruing large patient cohorts receiving the same drug regimen for GWA studies is challenging, and even more difficult may be performing a replication GWA in patients. Such replication studies should have been unconducted in subjects with analogous ethnic backgrounds since the relative impact of polymorphisms may differ depending on racial background. As a consequence, a large part of findings was identified retrospectively and presented some levels of biases; others were derived from relatively small-sized samples of patients and, though acquired prospectively, deserved confirmation in larger cohorts. The difficulty in conducting large prospective pharmacogenomic or pharmacoeconomic trials (preferentially through a phase III design or as independent study) has led in the past several years a large number of investigators to employ cell-based models as a component of their pharmacogenomic research program. Some researchers have used the International HapMap or the Polymorphism Discovery Panel LCLs, whereas other groups have created their own cell lines from individuals with a specific disease for study. Actually, with respect to cytarabine, stronger evidences for promising results and translational application come out when genetic variants observed in LCLs are replicated with clinical patient data as is the case of genetic variants of NT5C2 [151] and FKBP5 [222]. Anyway, discoveries made in LCLs also deserve to be verified for replication in clinical datasets, and this successfully happened in very few cases.

Methodological constraints for replication and validation studies still remain after the accessibility of genome sequence and introduction of the new analytical platforms repertoire including single nucleotide polymorphism arrays, gene expression profiling, and next generation sequencing.

Beyond the limitations due to the necessity of replication and validation studies, GWA approaches as issues and shortcomings strictly related to computational methodology and statistical analysis of the massive amounts of data achieved. These exceptional volumes of results are susceptible to an unprecedented potential for false positives because of the huge number of comparisons and statistical tests that are made using data on SNPs or expression across the genome [227]. Lack of well-defined case and control groups, insufficient sample size, control for multiple testing and control for population stratification 
are other common problems [227]. Due to inadequate sample extents, effect sizes are often biased upward with large standard errors, particularly in the case of SNPs with low minor allele frequencies [227]. Since these high-throughput genetic investigations have brought about new computational challenges in the analysis and ranking of discoveries intended to categorization of genetic loci potentially predictive of phenotype, collective expertise among statistic geneticists, genotyping laboratories, and clinical investigators is required for appropriate study setup and quality control. To partially obviate the heterogeneity of the results of GWA studies of cytarabine-induced cytotoxicity, meta-analysis was recently adopted by researchers [228]. Anyway, population differences and heterogeneity of hematologic tumors and other potential covariates, such as concomitant medications can confound pharmacogenomics correlations in pharmacogenomic studies combined in the meta-analysis. Tests of heterogeneity and watchful interpretation of final output should be adopted in these cases $[229,230]$. An additional resource may be represented by the use of Bayesian models which may allow also the sequential incorporation of new data as soon as they are produced, also from ongoing studies before ending [231,232].

Anyway, due to the rapidly decreasing price, the new technique of complete genome sequencing will provide in the next future a realistic alternative to genotyping array-based GWA studies and side-step some of the limitations of non-sequencing GWA [233].

With respect to economic costs, overviews of cost-effectiveness studies on pharmacogenetics and genomics technologies are now available [234,235], as well as solicitations from diagnostic advisory committee, such as the National Institute for Health and Clinical Excellence (NICE) to Pharma and Academic communities to output design and data sources in economic models of healthcare [236]. Anyway, only few studies have addressed the cost-effectiveness of pharmacogenomics testing implicated in clinical practice [235]. Platforms, such as the Affymetrix DMET chip and the Illumina ADME, allow a targeted evaluation of genes known to be related to cytarabine and phenotype of interest. Alternatively, a targeted exome or genome capture experiment could be considered if there is a list of genes hypothesized to be relevant. This latter approach will most likely only be relevant until the cost of whole-genome sequencing drops. Once the cost of sequencing the entire genome is low enough, this will be the method of choice as it enables one to obtain the rare variants as well as the common variants and everything in between.

However, the real impact of pharmacogenomics in predicting the response to cytarabinecontaining treatments and, consequently, refining a risk stratification that would translate into effective targeted therapies is still far from being defined. Several factors should be considered in determining clinical and prognostic significance of a novel genetic discovery: treatment schedule and concomitant medication, independent verification in multiple prospective clinical trials, independent prognostic value in multivariate analysis with consolidated prognostic factors, and the importance of the novel genetic aberration, either as potential targets or as modifiers of specific therapies.

Additional constraints come from the necessity of new study design. Refining treatment stratification and defining subgroups for targeted treatments are just the tip of the iceberg of more complex reality we have to face in designing future studies. In particular, when adding a new factor in the study protocol, one may consider the real distribution of the factor in the patient population, the significance of its role in terms of prognosis in combination with other consolidated prognostic factors and the probability that changing risk group (and thus the treatment intensity) for some patients may actually ameliorate their outcome [237]. For example in schedule including a BCL2 inhibitor Venetoclax, protocol-recommended dose modifications (50\%) for patients Poor metabolizers for CYP3A or patients receiving strong CYP3A inhibitors [38].

This evaluation should also be performed to avoid unnecessary complexity in the stratification system, which is relevant for trial design, feasibility, and generalizability of the results. 
Adding a new stratification factor would be worthwhile only if this increased the separation between risk groups while decreasing the with ingroup heterogeneity in terms of outcome.

\subsection{New Cytarabine Formulations}

Beyond the use of genetic make-up of patients to predict response to treatment, the progress in pharmacogenomics has brought in-depth knowledge of the mechanism of action of cytarabine and prompted the development of new compounds that could play independently of membrane transporters or kinases and are less susceptible to degradation. Therefore, while the demonstration of improved diagnostic prediction of the aforementioned genetic variants and their translation into clinical practice keep on pending and represent a still slow process, new formulations and cytotoxic analogues of cytarabine have shown promise in in vitro and animal models so prompting therapeutic clinical trials [21].

Protection of cytarabine from fast degradation and elimination has been primarily investigated, with the aim to prolong exposure of cells to cytotoxic concentrations. Since cytarabine is an S-phase specific drug an extended exposure of the cell to the drug is critical to achieve maximum cytotoxic activity. After encapsulation into pharmaceutically acceptable carriers and derivatives, cytarabine cannot be deaminated and seems to exhibit better pharmacokinetic parameters. As a consequence, new nucleotides with modified base- and sugar-moiety, pronucleotides, chemo conjugated analogues and liposomal formulations are contender to replace cytarabine in clinical practice, and even broaden therapeutic indications.

Conjugation of cytarabine to phospholipids, steroids or fatty acids can modify the pharmacokinetics of the drug ensuring easier transmembrane uptake, independent from diffusion facilitating systems, and lower sensitivity to deactivation by CDA [238,239].

\subsubsection{Elacytarabine}

Ela cytarabine and elainic-acid conjugated cytarabine, has shown to be able to bypass the effect of hENT inhibition on CCRF-CEM cell line and in patient samples [240]. In preclinical and clinical studies, elacytarabine has shown both safety and efficacy in AML, with remarkable activity among the cytarabine-refractory AML population [239]. Ela cytarabine has also shown safety in a phase III study enrolling 381 patients with AML, but the activity of elacytarabine was not predicted by hENT1 expression [241]. To date, no additional phase III trials was published after 2014.

\subsubsection{Sapacitabine}

A recent phase II study has explored in AML patients safety and activity of sapacitabine, an analogue of cytarabine incorporating a cyano group capable of nucleophilic attack with consequent strand breaks once incorporated into DNA [242]. Investigations of sapacitabine have demonstrated a novel action mechanism of causing a single-strand nick after its incorporation into DNA [243]. Differently from cytarabine, which causes stalling of replication forks and arrest in $S$ phase, the DNA breaks caused by sapacitabine activates the G2 checkpoint and cause an accumulation of cells in the G2 phase of the cell cycle [244,245]. However, single strand breaks induced by sapacitabine is contrasted by DNA repair complex genes that includes XRCC3, BRCA2, and RAD51 in AML [215].

Phase II trial are now exploring sapacitabine activity in chronic lymphoid leukemia and cutaneous T-cell lymphomas (ClinicalTrials.gov identifiers: NCT01253460 and NCT00476554).

\subsubsection{Pronucleotides}

Phosphorylated cytarabine analogues have been developed in which the phosphate moiety has been chemically masked so to increase hydrophobicity and facilitate entrance of the compound into the cell. The phosphodiester derivative of cytarabine UA911 has been able to circumvent DCK deficiency [246] while another pronucleotide, cytarabine phosphoramidate, has demonstrated better activity on hENT1- and DCK-deficient cells 
than cytarabine [247]. The addition of one or more S-acyl-2-thioethyl group to cytarabine monophosphate has been able, after the sequential actions of a non-specific esterase and a phosphodiesterase, to release into the cell the active metabolite and circumvent resistance mechanisms due to altered membrane transport or decreased DCK [248].

Activated metabolites of nucleoside analogs may also be conjugated to innovative polymeric nanogels. This formulation, beyond permitting oral administration due to its stability in the gastrointestinal tract, was capable of an efficient transport and intracellular delivery of active drug form and resulted in substantial tumor growth inhibition in drugresistant tumor xenograft animal model [249].

\subsubsection{Liposomal Formulations}

A liposomal sustained-release formulation for intrathecal administration of cytarabine is available for the treatment of lymphomatous meningitis; due to pharmacokinetic characteristics and half-life in CSF of 100-263 h protracted exposure to the drug may be achieved by cancer cells in liquor [25]. However, severe neurotoxicity has been reported in different retrospective studies. Transient chemical meningitis [250], permanent damages in about $10 \%$ of patients [251], exacerbations by concurrent administration of high-dose methotrexate [252,253] and the advice that any grade of adverse neurological events, that may affect the same group patients with all others completely free from any toxicity [254,255], suggest that a neurotoxicity to liposomal cytarabine may occur in an especially predisposed subset of patients.

The co-encapsulation of two or more synergic antineoplastic agents in the same liposomal device, that could serve as a springboard to reduce the effective drug dose and consequently soothe side effects, represents an innovative option in cancer therapy already adopted for improving the activity of pyrimidine analogues [256]. After positive results in an early-stage trial [257], the CPX-351, a liposomal multidrug carrier encapsulating cytarabine and daunorubicin, is under evaluation in children with relapsed acute myeloid leukemia (ClinicalTrials.gov identifier: NCT01943682) and adult patients with untreated myelodysplastic syndrome or acute myeloid leukemia at high risk of treatment-related mortality (ClinicalTrials.gov identifier: NCT01804101). This new combined formulation was FDA and EMA approved in 2018.

\section{Conclusions and Future Outlook}

The last decade has witnessed significant advances in genome-wide profiling technologies (e.g., microarray and the next-generation sequencing), thus opening up the possibilities for high-throughput profiling and measuring of various molecular targets including gene expression, genetic variations, and more recently, epigenetic variations. In the meantime, the launch of the Human Genome Project and other parallel large-scale projects such as the International HapMap Project [258,259] and the 1000 Genomes Project [260,261] has promoted an unprecedented improvement of our understanding of the human genetic variation from diverse global populations. Pharmacogenetic and pharmacogenomic studies on cytarabine have benefited from these technical advancements and scientific breakthroughs during the past decade.

The use in covert resistant diseases and the worrying profile of toxicities, even lifethreatening, have made cytarabine as one of the antineoplastic drugs most studied by pharmacogenetics and pharmacogenomics. Exploring drug transport and cellular metabolism as key determinants of pharmacokinetics and pharmacodynamics, as well as heterogeneity in response and toxicity profiles [20] has led to find out genetic determinants of response and toxicity to cytarabine. Indeed, the potential of genetic testing in the setting of clinical trials and practice remains largely unexploited. Since straightness and certainty of results from standard and GWA studies deserve repetition and validation in prospective clinical trials, also powered by properly devised statistical designs and analyses, a huge extra-time seems to be necessary to ascertain whether this strategy will eventually result in safer and more effective personalized treatments. We can expect more and sooner from the 
introduction of engineered variants of cytarabine that can bypass some critical steps of the metabolism and optimize intracellular performance of the drug. Progress seems more substantial and within reach for these new formulations where the drug is conjugated with lipids, or assembled in activated form as pronucleotides, or encapsulated in liposomal single or multi drug carrier.

The crosswise examination of cytarabine-related issues proposed in this article, ranging from the spectrum of clinical activity and severe toxicities, through updated cellular pharmacology and drug formulations, up to the genetic variants associated with druginduced phenotypes, has tried to arouse and maintain the interest of both basic researchers and the clinical hematologists. The opportunity of soothing or overcoming the serious adverse events related to cytarabine-based therapies and the hope of predicting response and circumventing drug-resistance phenomena can hopefully rely on the future implementation of the methods for genotyping the variants influencing cytarabine biotransformation, but above all on transversal cognizance and mutual confrontation about current boundaries of clinical practice and the multiplicity of the biological and translational acquisitions. Probably, more restrictive criteria for patient selection as well as further extension of the investigation to diseases other than AML, especially lymphoma, could eventually open up new opportunities and indications. A halfway acquaintance about the contests in treating patients and the exciting outlooks of genetic analysis would hopefully enhance investigation in leukemia and lymphoma patients of pharmacogenomics assumptions in clinical trials on cytarabine-centered therapies. If we take into account that mostly it deals with orphan diseases with not much room for large and well-powered studies, a greater awareness and a mutual encounter between geneticists and hematologists, prior to the involvement of statisticians and industry, represent the privileged way to connect the future of pharmacogenomics and outcome in leukemia and lymphoma patients even.

Supplementary Materials: The following are available online at https:/ / www.mdpi.com/2072-669 4/13/5/966/s1, Supplemental Table S1: CDA haplotype nomenclature.

Author Contributions: Conceptualization, A.P. and G.C.; methodology, R.D.F. (Raffaele Di Francia); software, A.D.M.; validation, C.C., A.M., R.D.F. (Rosaria De Filippi) and R.D.F. (Raffaele Di Francia); formal analysis, A.D.M.; investigation; resources S.C., G.I.; data curation, F.F.; writing-original draft preparation, R.D.F. (Raffaele Di Francia); writing-review and editing, G.C., C.C. and A.R.; supervision, G.C.; project administration S.C., A.P. All authors have read and agreed to the published version of the manuscript.

Funding: This research received no external funding.

Institutional Review Board Statement: Not applicable.

Informed Consent Statement: Not applicable.

Data Availability Statement: Not applicable.

Acknowledgments: A.M. thanks the Italian Ministry of Health and Fondazione Roma (Italy).

Conflicts of Interest: The authors declare no conflict of interest.

\section{References}

1. Burnett, A.; Wetzler, M.; Lowenberg, B. Therapeutic advances in acute myeloid leukemia. J. Clin. Oncol. 2011, 29, 487-494. [CrossRef]

2. Aldoss, I.T.; Weisenburger, D.D.; Fu, K.; Chan, W.C.; Vose, J.M.; Bierman, P.J.; Bociek, R.G.; Armitage, J.O. Adult Burkitt lymphoma: Advances in diagnosis and treatment. Oncology 2008, 22, 1508-1517.

3. Friedberg, J.W. Relapsed/refractory diffuse large B-cell lymphoma. Hematol. Am. Soc. Hematol. Educ. Program. 2011, 2011, 498-505. [CrossRef] [PubMed]

4. Gokbuget, N.; Hoelzer, D. Treatment of adult acute lymphoblastic leukemia. Semin. Hematol. 2009, 46, 64-75. [CrossRef]

5. Li, L.; Fridley, B.; Kalari, K.; Jenkins, G.; Batzler, A.; Safgren, S.; Hildebrandt, M.; Ames, M.; Schaid, D.; Wang, L. Gemcitabine and cytosine arabinoside cytotoxicity: Association with lymphoblastoid cell expression. Cancer Res. 2008, 68, 7050-7058. [CrossRef] [PubMed]

6. Ferrara, F.; Pinto, A. Acute myeloid leukemia in the elderly: Current therapeutic results and perspectives for clinical research Rev. Recent Clin. Trials 2007, 2, 33-41. [CrossRef] 
7. Gisselbrecht, C.; Glass, B.; Mounier, N.; Singh Gill, D.; Linch, D.C.; Trneny, M.; Bosly, A.; Ketterer, N.; Shpilberg, O.; Hagberg, H.; et al. Salvage regimens with autologous transplantation for relapsed large B-cell lymphoma in the rituximab era. J. Clin. Oncol. 2010, 28, 4184-4190. [CrossRef] [PubMed]

8. Seyfarth, B.; Josting, A.; Dreyling, M.; Schmitz, N. Relapse in common lymphoma subtypes: Salvage treatment options for follicular lymphoma, diffuse large cell lymphoma and Hodgkin disease. Br. J. Haematol. 2006, 133, 3-18. [CrossRef]

9. Chagnon, K.; Boissel, N.; Raffoux, E.; Dombret, H.; Tazi, A.; Bergeron, A. A new pattern of cytosine-arabinoside-induced lung toxicity. Br. J. Haematol. 2009, 147, 771-774. [CrossRef] [PubMed]

10. Ciccolini, J.; Evrard, A.; M’Batchi, L.; Pourroy, B.; Mercier, C.; Iliadis, A.; Lacarelle, B.; Verschuur, A.; Ouafik, L.; Andre, N. CDA deficiency as a possible culprit for life-threatening toxicities after cytarabine plus 6-mercaptopurine therapy: Pharmacogenetic investigations. Pharmacogenomics 2012, 13, 393-397. [CrossRef] [PubMed]

11. Abraham, A.; Varatharajan, S.; Abbas, S.; Zhang, W.; Shaji, R.V.; Ahmed, R.; Abraham, A.; George, B.; Srivastava, A.; Chandy, M.; et al. Cytidine deaminase genetic variants influence RNA expression and cytarabine cytotoxicity in acute myeloid leukemia. Pharmacogenomics 2012, 13, 269-282. [CrossRef]

12. Eron, J.J.; Benoit, S.L.; Jemsek, J.; MacArthur, R.D.; Santana, J.; Quinn, J.B.; Kuritzkes, D.R.; Fallon, M.A.; Rubin, M. Treatment with lamivudine, zidovudine, or both in HIV-positive patients with 200 to 500 CD4+ cells per cubic millimeter. North American HIV Working Party. N. Engl. J. Med. 1995, 333, 1662-1669. [CrossRef] [PubMed]

13. Evrard, A.; Lacarelle, B.; Ciccolini, J. Severe or lethal toxicities with nucleosidic analogs: Time for action. Pharmacogenomics 2013, 14, 227-230. [CrossRef]

14. Baker, W.J.; Royer Jr, G.L.; Weiss, R.B. Cytarabine and neurologic toxicity. J. Clin. Oncol. 1991, 9, 679-693. [CrossRef]

15. Relling, M.V.; Hancock, M.L.; Rivera, G.K.; Sandlund, J.T.; Ribeiro, R.C.; Krynetski, E.Y.; Pui, C.H.; Evans, W.E. Mercaptopurine therapy intolerance and heterozygosity at the thiopurine S-methyltransferase gene locus. J. Natl. Cancer Inst. 1999, 91, 2001-2008. [CrossRef]

16. Parmar, S.; Seeringer, A.; Denich, D.; Gartner, F.; Pitterle, K.; Syrovets, T.; Ohmle, B.; Stingl, J.C. Variability in transport and biotransformation of cytarabine is associated with its toxicity in peripheral blood mononuclear cells. Pharmacogenomics 2011, 12, 503-514. [CrossRef] [PubMed]

17. Lamba, J.K. Genetic factors influencing cytarabine therapy. Pharmacogenomics 2009, 10, 1657-1674. [CrossRef] [PubMed]

18. Paugh, S.W.; Stocco, G.; McCorkle, J.R.; Diouf, B.; Crews, K.R.; Evans, W.E. Cancer pharmacogenomics. Clin. Pharmacol. Ther. 2011, 90, 461-466. [CrossRef]

19. Davies, S.M. Pharmacogenetics, pharmacogenomics and personalized medicine: Are we there yet? Hematol. Am. Soc. Hematol. Educ. Program. 2006, 111-117. [CrossRef] [PubMed]

20. Wheeler, H.E.; Maitland, M.L.; Dolan, M.E.; Cox, N.J.; Ratain, M.J. Cancer pharmacogenomics: Strategies and challenges. Nat. Rev. Genet. 2013, 14, 23-34. [CrossRef] [PubMed]

21. Jordheim, L.P.; Durantel, D.; Zoulim, F.; Dumontet, C. Advances in the development of nucleoside and nucleotide analogues for cancer and viral diseases. Nat. Rev. Drug Discov. 2013, 12, 447-464. [CrossRef] [PubMed]

22. Sampath, D.; Rao, V.A.; Plunkett, W. Mechanisms of apoptosis induction by nucleoside analogs. Oncogene 2003, 22, 9063-9074. [CrossRef]

23. Hellström-Lindberg, E.; Robèrt, K.H.; Gahrton, G.; Lindberg, G.; Forsblom, A.M.; Kock, Y.; Ost, A. Low-dose ara-C in myelodysplastic syndromes (MDS) and acute leukemia following MDS: Proposal for a predictive model. Leuk. Lymphoma 1994, 12, 343-351. [CrossRef]

24. Ades, L.; Chevret, S.; Raffoux, E.; de Botton, S.; Guerci, A.; Pigneux, A.; Stoppa, A.M.; Lamy, T.; Rigal-Huguet, F.; Vekhoff, A.; et al. Is cytarabine useful in the treatment of acute promyelocytic leukemia? Results of a randomized trial from the European Acute Promyelocytic Leukemia Group. J. Clin. Oncol. 2006, 24, 5703-5710. [CrossRef]

25. McClune, B.; Buadi, F.K.; Aslam, N.; Przepiorka, D. Intrathecal liposomal cytarabine for prevention of meningeal disease in patients with acute lymphocytic leukemia and high-grade lymphoma. Leuk. Lymphoma 2007, 48, 1849-1851. [CrossRef]

26. Gokbuget, N.; Hartog, C.M.; Bassan, R.; Derigs, H.G.; Dombret, H.; Greil, R.; Hernandez-Rivas, J.M.; Huguet, F.; Intermesoli, T.; Jourdan, E.; et al. Liposomal cytarabine is effective and tolerable in the treatment of central nervous system relapse of acute lymphoblastic leukemia and very aggressive lymphoma. Haematologica 2011, 96, 238-244. [CrossRef]

27. Olmos-Jimenez, R.; Diaz-Carrasco, M.S.; Galera-Minarro, A.; Pascual-Gazquez, J.F.; Espuny-Miro, A. Evaluation of standardized triple intrathecal therapy toxicity in oncohematological pediatric patients. Int. J. Clin. Pharm. 2017, 39, 126-132. [CrossRef] [PubMed]

28. Tilly, H.; Castaigne, S.; Bordessoule, D.; Casassus, P.; Le Prise, P.Y.; Tertian, G.; Desablens, B.; Henry-Amar, M.; Degos, L. Low-dose cytarabine versus intensive chemotherapy in the treatment of acute nonlymphcytic leukemia in the elderly. J. Clin. Oncol. 1990, 8, 272-279. [CrossRef]

29. Fenaux, P.; Mufti, G.J.; Hellstrom-Lindberg, E.; Santini, V.; Gattermann, N.; Germing, U.; Sanz, G.; List, A.F.; Gore, S.; Seymour, J.F.; et al. Azacitidine prolongs overall survival compared with conventional care regimens in elderly patients with low bone marrow blast count acute myeloid leukemia. J. Clin. Oncol. 2010, 28, 562-569. [CrossRef] [PubMed]

30. Burnett, A.K.; Milligan, D.; Prentice, A.G.; Goldstone, A.H.; McMullin, M.F.; Hills, R.K.; Wheatley, K. A comparison of low-dose cytarabine and hydroxyurea with or without all-trans retinoic acid for acute myeloid leukemia and high-risk myelodysplastic syndrome in patients not considered fit for intensive treatment. Cancer 2007, 109, 1114-1124. [CrossRef] 
31. Herzig, R.H.; Lazarus, H.M.; Wolff, S.N.; Phillips, G.L.; Herzig, G.P. High-dose cytosine arabinoside therapy with and without anthracycline antibiotics for remission reinduction of acute nonlymphoblastic leukemia. J. Clin. Oncol. 1985, 3, 992-997. [CrossRef] [PubMed]

32. Mayer, R.J.; Davis, R.B.; Schiffer, C.A.; Berg, D.T.; Powell, B.L.; Schulman, P.; Omura, G.A.; Moore, J.O.; McIntyre, O.R.; Frei, E., 3rd. Intensive postremission chemotherapy in adults with acute myeloid leukemia. Cancer and Leukemia Group B. N. Engl. J. Med. 1994, 331, 896-903. [CrossRef] [PubMed]

33. Byrd, J.C.; Ruppert, A.S.; Mrozek, K.; Carroll, A.J.; Edwards, C.G.; Arthur, D.C.; Pettenati, M.J.; Stamberg, J.; Koduru, P.R.; Moore, J.O.; et al. Repetitive cycles of high-dose cytarabine benefit patients with acute myeloid leukemia and inv(16)(p13q22) or $\mathrm{t}(16 ; 16)(\mathrm{p} 13 ; \mathrm{q} 22)$ : Results from CALGB 8461. J. Clin. Oncol. 2004, 22, 1087-1094. [CrossRef]

34. Schlenk, R.F. Post-remission therapy for acute myeloid leukemia. Haematologica 2014, 99, 1663-1670. [CrossRef] [PubMed]

35. Rowe, J.M. Optimal induction and post-remission therapy for AML in first remission. Hematol. Am. Soc. Hematol. Educ. Program. 2009, 2009, 396-405. [CrossRef]

36. Lowenberg, B. Sense and nonsense of high-dose cytarabine for acute myeloid leukemia. Blood 2013, 121, 26-28. [CrossRef]

37. Lowenberg, B.; Pabst, T.; Vellenga, E.; van Putten, W.; Schouten, H.C.; Graux, C.; Ferrant, A.; Sonneveld, P.; Biemond, B.J.; Gratwohl, A.; et al. Cytarabine dose for acute myeloid leukemia. N. Engl. J. Med. 2011, 364, 1027-1036. [CrossRef] [PubMed]

38. Wei, A.H.; Montesinos, P.; Ivanov, V.; DiNardo, C.D.; Novak, J.; Laribi, K.; Kim, I.; Stevens, D.A.; Fiedler, W.; Pagoni, M.; et al. Venetoclax plus LDAC for newly diagnosed AML ineligible for intensive chemotherapy: A phase 3 randomized placebo-controlled trial. Blood 2020, 135, 2137-2145. [CrossRef] [PubMed]

39. Arlin, Z.; Case, D.C., Jr.; Moore, J.; Wiernik, P.; Feldman, E.; Saletan, S.; Desai, P.; Sia, L.; Cartwright, K. Randomized multicenter trial of cytosine arabinoside with mitoxantrone or daunorubicin in previously untreated adult patients with acute nonlymphocytic leukemia (ANLL). Lederle Cooperative Group. Leukemia 1990, 4, 177-183.

40. Wiernik, P.H.; Banks, P.L.; Case Jr, D.C.; Arlin, Z.A.; Periman, P.O.; Todd, M.B.; Ritch, P.S.; Enck, R.E.; Weitberg, A.B. Cytarabine plus idarubicin or daunorubicin as induction and consolidation therapy for previously untreated adult patients with acute myeloid leukemia. Blood 1992, 79, 313-319. [CrossRef]

41. Dillman, R.O.; Davis, R.B.; Green, M.R.; Weiss, R.B.; Gottlieb, A.J.; Caplan, S.; Kopel, S.; Preisler, H.; McIntyre, O.R.; Schiffer, C. A comparative study of two different doses of cytarabine for acute myeloid leukemia: A phase III trial of Cancer and Leukemia Group B. Blood 1991, 78, 2520-2526. [CrossRef] [PubMed]

42. Fernandez, H.F.; Sun, Z.; Yao, X.; Litzow, M.R.; Luger, S.M.; Paietta, E.M.; Racevskis, J.; Dewald, G.W.; Ketterling, R.P.; Bennett, J.M.; et al. Anthracycline dose intensification in acute myeloid leukemia. N. Eng. J. Med. 2009, 361, 1249-1259. [CrossRef]

43. Bishop, J.F.; Matthews, J.P.; Young, G.A.; Szer, J.; Gillett, A.; Joshua, D.; Bradstock, K.; Enno, A.; Wolf, M.M.; Fox, R.; et al. A randomized study of high-dose cytarabine in induction in acute myeloid leukemia. Blood 1996, 87, 1710-1717. [CrossRef] [PubMed]

44. Milligan, D.W.; Wheatley, K.; Littlewood, T.; Craig, J.I.; Burnett, A.K.; Group NHOCS. Fludarabine and cytosine are less effective than standard ADE chemotherapy in high-risk acute myeloid leukemia, and addition of G-CSF and ATRA are not beneficial: Results of the MRC AML-HR randomized trial. Blood 2006, 107, 4614-4622. [CrossRef] [PubMed]

45. Wrzesien-Kus, A.; Robak, T.; Lech-Maranda, E.; Wierzbowska, A.; Dmoszynska, A.; Kowal, M.; Holowiecki, J.; Kyrcz-Krzemien, S.; Grosicki, S.; Maj, S.; et al. A multicenter, open, non-comparative, phase II study of the combination of cladribine (2chlorodeoxyadenosine), cytarabine, and G-CSF as induction therapy in refractory acute myeloid leukemia-a report of the Polish Adult Leukemia Group (PALG). Eur. J. Haematol. 2003, 71, 155-162. [CrossRef] [PubMed]

46. Wierzbowska, A.; Robak, T.; Pluta, A.; Wawrzyniak, E.; Cebula, B.; Holowiecki, J.; Kyrcz-Krzemien, S.; Grosicki, S.; Giebel, S.; Skotnicki, A.B.; et al. Cladribine combined with high doses of arabinoside cytosine, mitoxantrone, and G-CSF (CLAG-M) is a highly effective salvage regimen in patients with refractory and relapsed acute myeloid leukemia of the poor risk: A final report of the Polish Adult Leukemia Group. Eur. J. Haematol. 2008, 80, 115-126.

47. Montillo, M.; Mirto, S.; Petti, M.C.; Latagliata, R.; Magrin, S.; Pinto, A.; Zagonel, V.; Mele, G.; Tedeschi, A.; Ferrara, F. Fludarabine, cytarabine, and G-CSF (FLAG) for the treatment of poor risk acute myeloid leukemia. Am. J. Hematol. 1998, 58, 105-109. [CrossRef]

48. Amadori, S.; Arcese, W.; Isacchi, G.; Meloni, G.; Petti, M.C.; Monarca, B.; Testi, A.M.; Mandelli, F. Mitoxantrone, etoposide, and intermediate-dose cytarabine: An effective and tolerable regimen for the treatment of refractory acute myeloid leukemia. J. Clin. Oncol. 1991, 9, 1210-1214. [CrossRef]

49. Archimbaud, E.; Thomas, X.; Leblond, V.; Michallet, M.; Fenaux, P.; Cordonnier, C.; Dreyfus, F.; Troussard, X.; Jaubert, J.; Travade, P.; et al. Timed sequential chemotherapy for previously treated patients with acute myeloid leukemia: Long-term follow-up of the etoposide, mitoxantrone, and cytarabine-86 trial. J. Clin. Oncol. 1995, 13, 11-18. [CrossRef]

50. Ades, L.; Sanz, M.A.; Chevret, S.; Montesinos, P.; Chevallier, P.; Raffoux, E.; Vellenga, E.; Guerci, A.; Pigneux, A.; Huguet, F.; et al. Treatment of newly diagnosed acute promyelocytic leukemia (APL): A comparison of French-Belgian-Swiss and PETHEMA results. Blood 2008, 111, 1078-1084. [CrossRef]

51. Powell, B.L.; Moser, B.; Stock, W.; Gallagher, R.E.; Willman, C.L.; Stone, R.M.; Rowe, J.M.; Coutre, S.; Feusner, J.H.; Gregory, J.; et al. Arsenic trioxide improves event-free and overall survival for adults with acute promyelocytic leukemia: North American Leukemia Intergroup Study C9710. Blood 2010, 116, 3751-3757. [CrossRef] [PubMed] 
52. Rizzieri, D.A.; Johnson, J.L.; Niedzwiecki, D.; Lee, E.J.; Vardiman, J.W.; Powell, B.L.; Barcos, M.; Bloomfield, C.D.; Schiffer, C.A.; Peterson, B.A.; et al. Intensive chemotherapy with and without cranial radiation for Burkitt leukemia and lymphoma: Final results of Cancer and Leukemia Group B Study 9251. Cancer 2004, 100, 1438-1448. [CrossRef]

53. Mead, G.M.; Barrans, S.L.; Qian, W.; Walewski, J.; Radford, J.A.; Wolf, M.; Clawson, S.M.; Stenning, S.P.; Yule, C.L.; Jack, A.S.; et al. A prospective clinicopathologic study of dose-modified CODOX-M/IVAC in patients with sporadic Burkitt lymphoma defined using cytogenetic and immunophenotypic criteria (MRC/NCRI LY10 trial). Blood 2008, 112, 2248-2260. [CrossRef] [PubMed]

54. Kantarjian, H.M.; O’Brien, S.; Smith, T.L.; Cortes, J.; Giles, F.J.; Beran, M.; Pierce, S.; Huh, Y.; Andreeff, M.; Koller, C.; et al. Results of treatment with hyper-CVAD, a dose-intensive regimen, in adult acute lymphocytic leukemia. J. Clin. Oncol. 2000, 18, 547-561. [CrossRef] [PubMed]

55. Stock, W.; Johnson, J.L.; Stone, R.M.; Kolitz, J.E.; Powell, B.L.; Wetzler, M.; Westervelt, P.; Marcucci, G.; DeAngelo, D.J.; Vardiman, J.W.; et al. Dose intensification of daunorubicin and cytarabine during treatment of adult acute lymphoblastic leukemia: Results of Cancer and Leukemia Group B Study 19802. Cancer 2013, 119, 90-98. [CrossRef] [PubMed]

56. Zheng, X.; Yang, S.; Chen, F.; Wu, S.; Li, W. The Efficacy and Safety of Cytarabine on Newly Diagnosed Primary Central Nervous System Lymphoma: A Systematic Review and Meta-Analysis. Front. Oncol. 2020, 10, 1213. [CrossRef] [PubMed]

57. Visco, C.; Finotto, S.; Zambello, R.; Paolini, R.; Menin, A.; Zanotti, R.; Zaja, F.; Semenzato, G.; Pizzolo, G.; D’Amore, E.S.; et al. Combination of rituximab, bendamustine, and cytarabine for patients with mantle-cell non-Hodgkin lymphoma ineligible for intensive regimens or autologous transplantation. J. Clin. Oncol. 2013, 31, 1442-1449. [CrossRef]

58. Bernstein, S.H.; Epner, E.; Unger, J.M.; Leblanc, M.; Cebula, E.; Burack, R.; Rimsza, L.; Miller, T.P.; Fisher, R.I. A phase II multicenter trial of hyperCVAD MTX/Ara-C and rituximab in patients with previously untreated mantle cell lymphoma; SWOG 0213. Ann. Oncol. 2013, 24, 1587-1593. [CrossRef]

59. Romero, D. Haematological cancer: Cytarabine-new standard of care for MCL. Nat. Rev. Clin. Oncol. 2016, 13, 464-465. [CrossRef] [PubMed]

60. Velasquez, W.S.; McLaughlin, P.; Tucker, S.; Hagemeister, F.B.; Swan, F.; Rodriguez, M.A.; Romaguera, J.; Rubenstein, E.; Cabanillas, F. ESHAP-an effective chemotherapy regimen in refractory and relapsing lymphoma: A 4-year follow-up study. J. Clin. Oncol. 1994, 12, 1169-1176. [CrossRef]

61. Machover, D.; Delmas-Marsalet, B.; Misra, S.C.; Gumus, Y.; Goldschmidt, E.; Schilf, A.; Frenoy, N.; Emile, J.F.; Debuire, B.; Guettier, C.; et al. Dexamethasone, high-dose cytarabine, and oxaliplatin (DHAOx) as salvage treatment for patients with initially refractory or relapsed non-Hodgkin's lymphoma. Ann. Oncol. 2001, 12, 1439-1443. [CrossRef]

62. Josting, A.; Rudolph, C.; Reiser, M.; Mapara, M.; Sieber, M.; Kirchner, H.H.; Dorken, B.; Hossfeld, D.K.; Diehl, V.; Engert, A.; et al. Time-intensified dexamethasone/cisplatin/cytarabine: An effective salvage therapy with low toxicity in patients with relapsed and refractory Hodgkin's disease. Ann. Oncol. 2002, 13, 1628-1635. [CrossRef]

63. Aparicio, J.; Segura, A.; Garcera, S.; Oltra, A.; Santaballa, A.; Yuste, A.; Pastor, M. ESHAP is an active regimen for relapsing Hodgkin's disease. Ann. Oncol. 1999, 10, 593-595. [CrossRef] [PubMed]

64. Chopra, R.; McMillan, A.K.; Linch, D.C.; Yuklea, S.; Taghipour, G.; Pearce, R.; Patterson, K.G.; Goldstone, A.H. The place of high-dose BEAM therapy and autologous bone marrow transplantation in poor-risk Hodgkin's disease. A single-center eight-year study of 155 patients. Blood 1993, 81, 1137-1145. [CrossRef] [PubMed]

65. Giebel, S.; Kruzel, T.; Czerw, T.; Sadus-Wojciechowska, M.; Najda, J.; Chmielowska, E.; Grosicki, S.; Jurczyszyn, A.; Pasiarski, M.; Nowara, E.; et al. Intermediate-dose Ara-C plus G-CSF for stem cell mobilization in patients with lymphoid malignancies, including predicted poor mobilizers. Bone Marrow Transpl. 2013, 48, 915-921. [CrossRef]

66. Ferreri, A.J.; Reni, M.; Foppoli, M.; Martelli, M.; Pangalis, G.A.; Frezzato, M.; Cabras, M.G.; Fabbri, A.; Corazzelli, G.; Ilariucci, F.; et al. High-dose cytarabine plus high-dose methotrexate versus high-dose methotrexate alone in patients with primary CNS lymphoma: A randomised phase 2 trial. Lancet 2009, 374, 1512-1520. [CrossRef]

67. Larson, R.A.; Dodge, R.K.; Burns, C.P.; Lee, E.J.; Stone, R.M.; Schulman, P.; Duggan, D.; Davey, F.R.; Sobol, R.E.; Frankel, S.R.; et al. A five-drug remission induction regimen with intensive consolidation for adults with acute lymphoblastic leukemia: Cancer and leukemia group B study 8811. Blood 1995, 85, 2025-2037. [CrossRef]

68. Weiss, M.A.; Aliff, T.B.; Tallman, M.S.; Frankel, S.R.; Kalaycio, M.E.; Maslak, P.G.; Jurcic, J.G.; Scheinberg, D.A.; Roma, T.E. A single, high dose of idarubicin combined with cytarabine as induction therapy for adult patients with recurrent or refractory acute lymphoblastic leukemia. Cancer 2002, 95, 581-587. [CrossRef]

69. Tsimberidou, A.M.; Wierda, W.G.; Plunkett, W.; Kurzrock, R.; O’Brien, S.; Wen, S.; Ferrajoli, A.; Ravandi-Kashani, F.; GarciaManero, G.; Estrov, Z.; et al. Phase I-II study of oxaliplatin, fludarabine, cytarabine, and rituximab combination therapy in patients with Richter's syndrome or fludarabine-refractory chronic lymphocytic leukemia. J. Clin. Oncol. 2008, 26, 196-203. [CrossRef]

70. Lee, E.J.; Petroni, G.R.; Schiffer, C.A.; Freter, C.E.; Johnson, J.L.; Barcos, M.; Frizzera, G.; Bloomfield, C.D.; Peterson, B.A. Brief-duration high-intensity chemotherapy for patients with small noncleaved-cell lymphoma or FAB L3 acute lymphocytic leukemia: Results of cancer and leukemia group B study 9251. J. Clin. Oncol. 2001, 19, 4014-4022. [CrossRef] [PubMed]

71. Velasquez, W.S.; Cabanillas, F.; Salvador, P.; McLaughlin, P.; Fridrik, M.; Tucker, S.; Jagannath, S.; Hagemeister, F.B.; Redman, J.R.; Swan, F.; et al. Effective salvage therapy for lymphoma with cisplatin in combination with high-dose Ara-C and dexamethasone (DHAP). Blood 1988, 71, 117-122. [CrossRef] 
72. McGrail, L.H.; Sehn, L.H.; Weiss, R.B.; Robson, M.R.; Antin, J.H.; Byrd, J.C. Pancreatitis during therapy of acute myeloid leukemia: Cytarabine related? Ann. Oncol. 1999, 10, 1373-1376. [CrossRef] [PubMed]

73. McBride, C.E.; Yavorski, R.T.; Moses, F.M.; Robson, M.E.; Solimando, D.A., Jr.; Byrd, J.C. Acute pancreatitis associated with continuous infusion cytarabine therapy: A case report. Cancer 1996, 77, 2588-2591. [CrossRef]

74. Powell, B.L.; Zekan, P.J.; Muss, H.B.; Richards, F., 2nd; Lyerly, E.S.; Capizzi, R.L. Ara-C syndrome during low-dose continuous infusion therapy. Med. Pediatr. Oncol. 1986, 14, 310-312. [CrossRef] [PubMed]

75. Phillips, C.L.; Lane, A.; Gerbing, R.B.; Alonzo, T.A.; Wilkey, A.; Radloff, G.; Lange, B.; Gamazon, E.R.; Dolan, M.E.; Davies, S.M. Genomic Variants of Cytarabine Sensitivity Associated with Treatment-Related Mortality in Pediatric AML: A Report from the Children's Oncology Group. Clin. Cancer Res. 2020, 26, 2891-2897. [CrossRef]

76. Moore, J.O.; George, S.L.; Dodge, R.K.; Amrein, P.C.; Powell, B.L.; Kolitz, J.E.; Baer, M.R.; Davey, F.R.; Bloomfield, C.D.; Larson, R.A.; et al. Sequential multiagent chemotherapy is not superior to high-dose cytarabine alone as postremission intensification therapy for acute myeloid leukemia in adults under 60 years of age: Cancer and Leukemia Group B Study 9222. Blood 2005, 105, 3420-3427. [CrossRef] [PubMed]

77. Herzig, R.H.; Hines, J.D.; Herzig, G.P.; Wolff, S.N.; Cassileth, P.A.; Lazarus, H.M.; Adelstein, D.J.; Brown, R.A.; Coccia, P.F.; Strandjord, S.; et al. Cerebellar toxicity with high-dose cytosine arabinoside. J. Clin. Oncol. 1987, 5, 927-932. [CrossRef] [PubMed]

78. Salinsky, M.C.; Levine, R.L.; Aubuchon, J.P.; Schutta, H.S. Acute cerebellar dysfunction with high-dose ARA-C therapy. Cancer 1983, 51, 426-429. [CrossRef]

79. Dunton, S.F.; Nitschke, R.; Spruce, W.E.; Bodensteiner, J.; Krous, H.F. Progressive ascending paralysis following administration of intrathecal and intravenous cytosine arabinoside. A Pediatric Oncology Group study. Cancer 1986, 57, 1083-1088. [CrossRef]

80. Openshaw, H.; Slatkin, N.E.; Stein, A.S.; Hinton, D.R.; Forman, S.J. Acute polyneuropathy after high dose cytosine arabinoside in patients with leukemia. Cancer 1996, 78, 1899-1905. [CrossRef]

81. Ventura, G.J.; Keating, M.J.; Castellanos, A.M.; Glass, J.P. Reversible bilateral lateral rectus muscle palsy associated with high-dose cytosine arabinoside and mitoxantrone therapy. Cancer 1986, 58, 1633-1635. [CrossRef]

82. Damon, L.E.; Mass, R.; Linker, C.A. The association between high-dose cytarabine neurotoxicity and renal insufficiency. J. Clin. Oncol. 1989, 7, 1563-1568. [CrossRef]

83. Nagahata, Y.; Kondo, T.; Ono, Y.; Hiramoto, N.; Kitano, T.; Hishizawa, M.; Yamashita, K.; Hashimoto, H.; Ishikawa, T.; TakaoriKondo, A. High-dose cytarabine chemotherapy $(>/=4 \mathrm{~g} / \mathrm{m}(2) /$ day) before allogeneic hematopoietic stem cell transplantation for non-core-binding-factor AML in the first complete remission. Leuk. Lymphoma 2020, 61, 3128-3136. [CrossRef]

84. Haupt, H.M.; Hutchins, G.M.; Moore, G.W. Ara-C lung: Noncardiogenic pulmonary edema complicating cytosine arabinoside therapy of leukemia. Am. J. Med. 1981, 70, 256-261. [CrossRef]

85. Deangelis, L.M.; Posner, J.B. Side effects of chemotherapy. In Neurologic Complications of Cancer, 2nd ed.; OUP: New York, NY, USA, 2009; p. 447.

86. Resar, L.M.; Phillips, P.C.; Kastan, M.B.; Leventhal, B.G.; Bowman, P.W.; Civin, C.I. Acute neurotoxicity after intrathecal cytosine arabinoside in two adolescents with acute lymphoblastic leukemia of B-cell type. Cancer 1993, 71, 117-123. [CrossRef]

87. Derissen, E.J.B.; Beijnen, J.H. Intracellular Pharmacokinetics of Pyrimidine Analogues used in Oncology and the Correlation with Drug Action. Clin. Pharm. 2020, 59, 1521-1550. [CrossRef] [PubMed]

88. Chou, T.C.; Hutchinson, D.J.; Schmid, F.A.; Philips, F.S. Metabolism and selective effects of 1-beta-D-arabinofuranosylcytosine in L1210 and Host tissues in vivo. Cancer Res. 1975, 35, 225-236. [PubMed]

89. Kufe, D.W.; Spriggs, D.R. Biochemical and cellular pharmacology of cytosine arabinoside. Semin. Oncol. 1985, 12 (Suppl. 3), $34-48$.

90. Galmarini, C.M.; Mackey, J.R.; Dumontet, C. Nucleoside analogues: Mechanisms of drug resistance and reversal strategies. Leukemia 2001, 15, 875-890. [CrossRef]

91. Clarke, M.L.; Mackey, J.R.; Baldwin, S.A.; Young, J.D.; Cass, C.E. The role of membrane transporters in cellular resistance to anticancer nucleoside drugs. Cancer Treat. Res. 2002, 112, 27-47. [PubMed]

92. Clarke, M.L.; Damaraju, V.L.; Zhang, J.; Mowles, D.; Tackaberry, T.; Lang, T.; Smith, K.M.; Young, J.D.; Tomkinson, B.; Cass, C.E. The role of human nucleoside transporters in cellular uptake of $4^{\prime}$-thio-beta-D-arabinofuranosylcytosine and beta-Darabinosylcytosine. Mol. Pharmacol. 2006, 70, 303-310. [CrossRef] [PubMed]

93. Endo, Y.; Obata, T.; Murata, D.; Ito, M.; Sakamoto, K.; Fukushima, M.; Yamasaki, Y.; Yamada, Y.; Natsume, N.; Sasaki, T. Cellular localization and functional characterization of the equilibrative nucleoside transporters of antitumor nucleosides. Cancer Sci. 2007, 98, 1633-1637. [CrossRef]

94. Galmarini, C.M.; Thomas, X.; Calvo, F.; Rousselot, P.; Rabilloud, M.; El Jaffari, A.; Cros, E.; Dumontet, C. In vivo mechanisms of resistance to cytarabine in acute myeloid leukaemia. Br. J. Haematol. 2002, 117, 860-868. [CrossRef] [PubMed]

95. Sarkar, M.; Han, T.; Damaraju, V.; Carpenter, P.; Cass, C.E.; Agarwal, R.P. Cytosine arabinoside affects multiple cellular factors and induces drug resistance in human lymphoid cells. Biochem. Pharmacol. 2005, 70, 426-432. [CrossRef]

96. Yee, S.W.; Mefford, J.A.; Singh, N.; Percival, M.E.; Stecula, A.; Yang, K.; Witte, J.S.; Takahashi, A.; Kubo, M.; Matsuda, K.; et al. Impact of polymorphisms in drug pathway genes on disease-free survival in adults with acute myeloid leukemia. J. Hum. Genet. 2013, 58, 353-361. [CrossRef]

97. Errasti-Murugarren, E.; Pastor-Anglada, M.; Casado, F.J. Role of CNT3 in the transepithelial flux of nucleosides and nucleosidederived drugs. J. Physiol 2007, 582 Pt 3, 1249-1260. [CrossRef] 
98. Li, L.; Fridley, B.L.; Kalari, K.; Jenkins, G.; Batzler, A.; Weinshilboum, R.M.; Wang, L. Gemcitabine and arabinosylcytosin pharmacogenomics: Genome-wide association and drug response biomarkers. PLoS ONE 2009, 4, e7765. [CrossRef]

99. Guo, Y.; Kock, K.; Ritter, C.A.; Chen, Z.S.; Grube, M.; Jedlitschky, G.; Illmer, T.; Ayres, M.; Beck, J.F.; Siegmund, W.; et al. Expression of ABCC-type nucleotide exporters in blasts of adult acute myeloid leukemia: Relation to long-term survival. Clin. Cancer Res. 2009, 15, 1762-1769. [CrossRef] [PubMed]

100. Hopper-Borge, E.; Xu, X.; Shen, T.; Shi, Z.; Chen, Z.S.; Kruh, G.D. Human multidrug resistance protein 7 (ABCC10) is a resistance factor for nucleoside analogues and epothilone B. Cancer Res. 2009, 69, 178-184. [CrossRef]

101. Gati, W.P.; Paterson, A.R.; Larratt, L.M.; Turner, A.R.; Belch, A.R. Sensitivity of acute leukemia cells to cytarabine is a correlate of cellular es nucleoside transporter site content measured by flow cytometry with SAENTA-fluorescein. Blood 1997, 90, 346-353. [CrossRef] [PubMed]

102. Zhang, J.; Visser, F.; King, K.M.; Baldwin, S.A.; Young, J.D.; Cass, C.E. The role of nucleoside transporters in cancer chemotherapy with nucleoside drugs. Cancer Metastasis Rev. 2007, 26, 85-110. [CrossRef] [PubMed]

103. Eltzschig, H.K.; Abdulla, P.; Hoffman, E.; Hamilton, K.E.; Daniels, D.; Schonfeld, C.; Loffler, M.; Reyes, G.; Duszenko, M.; Karhausen, J.; et al. HIF-1-dependent repression of equilibrative nucleoside transporter (ENT) in hypoxia. J. Exp. Med. 2005, 202, 1493-1505. [CrossRef] [PubMed]

104. Montero, T.D.; Racordon, D.; Bravo, L.; Owen, G.I.; Bronfman, M.L.; Leisewitz, A.V. PPARalpha and PPARgamma regulate the nucleoside transporter hENT1. Biochem. Biophys. Res. Commun. 2012, 419, 405-411. [CrossRef]

105. Galmarini, C.M.; Thomas, X.; Calvo, F.; Rousselot, P.; El Jafaari, A.; Cros, E.; Dumontet, C. Potential mechanisms of resistance to cytarabine in AML patients. Leuk. Res. 2002, 26, 621-629. [CrossRef]

106. Hubeek, I.; Stam, R.W.; Peters, G.J.; Broekhuizen, R.; Meijerink, J.P.; van Wering, E.R.; Gibson, B.E.; Creutzig, U.; Zwaan, C.M.; Cloos, J.; et al. The human equilibrative nucleoside transporter 1 mediates in vitro cytarabine sensitivity in childhood acute myeloid leukaemia. Br. J. Cancer 2005, 93, 1388-1394. [CrossRef] [PubMed]

107. White, J.C.; Rathmell, J.P.; Capizzi, R.L. Membrane transport influences the rate of accumulation of cytosine arabinoside in human leukemia cells. J. Clin. Investig. 1987, 79, 380-387. [CrossRef]

108. Kessel, D.; Hall, T.C.; Rosenthal, D. Uptake and phosphorylation of cytosine arabinoside by normal and leukemic human blood cells in vitro. Cancer Res. 1969, 29, 459-463.

109. Chou, T.C.; Arlin, Z.; Clarkson, B.D.; Phillips, F.S. Metabolism of 1-beta-D-arabinofuranosylcytosine in human leukemic cells. Cancer Res. 1977, 37, 3561-3570.

110. Heinemann, V.; Hertel, L.W.; Grindey, G.B.; Plunkett, W. Comparison of the cellular pharmacokinetics and toxicity of $2^{\prime}, 2^{\prime}-$ difluorodeoxycytidine and 1-beta-D-arabinofuranosylcytosine. Cancer Res. 1988, 48, 4024-4031.

111. Graham, F.L.; Whitmore, G.F. Studies in mouse L-cells on the incorporation of 1-beta-D-arabinofuranosylcytosine into DNA and on inhibition of DNA polymerase by 1-beta-D-arabinofuranosylcytosine 5'-triphosphate. Cancer Res. 1970, 30, $2636-2644$. [PubMed]

112. Rustum, Y.M.; Raymakers, R.A. 1-Beta-arabinofuranosylcytosine in therapy of leukemia: Preclinical and clinical overview. Pharmacol. Ther. 1992, 56, 307-321. [CrossRef]

113. Townsend, A.J.; Cheng, Y.C. Sequence-specific effects of ara-5-aza-CTP and ara-CTP on DNA synthesis by purified human DNA polymerases in vitro: Visualization of chain elongation on a defined template. Mol. Pharmacol. 1987, 32, 330-339. [PubMed]

114. Ross, D.D.; Cuddy, D.P.; Cohen, N.; Hensley, D.R. Mechanistic implications of alterations in HL-60 cell nascent DNA after exposure to 1-beta-D-arabinofuranosylcytosine. Cancer Chemother. Pharmacol. 1992, 31, 61-70. [CrossRef]

115. Kufe, D.; Spriggs, D.; Egan, E.M.; Munroe, D. Relationships among Ara-CTP pools, formation of (Ara-C)DNA, and cytotoxicity of human leukemic cells. Blood 1984, 64, 54-58. [CrossRef]

116. Preisler, H.D.; Rustum, Y.; Priore, R.L. Relationship between leukemic cell retention of cytosine arabinoside triphosphate and the duration of remission in patients with acute non-lymphocytic leukemia. Eur. J. Cancer Clin. Oncol. 1985, 21, 23-30. [CrossRef]

117. Plunkett, W.; Iacoboni, S.; Estey, E.; Danhauser, L.; Liliemark, J.O.; Keating, M.J. Pharmacologically directed ara-C therapy for refractory leukemia. Semin. Oncol. 1985, 12 (Suppl. 3), 20-30.

118. Plunkett, W.; Liliemark, J.O.; Adams, T.M.; Nowak, B.; Estey, E.; Kantarjian, H.; Keating, M.J. Saturation of 1-beta-Darabinofuranosylcytosine $5^{\prime}$-triphosphate accumulation in leukemia cells during high-dose 1-beta-D-arabinofuranosylcytosine therapy. Cancer Res. 1987, 47, 3005-3011. [PubMed]

119. Lauzon, G.J.; Paterson, A.R.; Belch, A.W. Formation of 1-beta-D-arabinofuranosylcytosine diphosphate choline in neoplastic and normal cells. Cancer Res. 1978, 38, 1730-1733.

120. Sasvari-Szekely, M.; Spasokukotskaja, T.; Staub, M. Deoxyribocytidine is salvaged not only into DNA but also into phospholipid precursors. IV. Exogenous deoxyribocytidine can be used with the same efficacy as (ribo)cytidine for lipid activation. Biochem. Biophys. Res. Commun. 1993, 194, 966-972. [CrossRef] [PubMed]

121. Chiba, P.; Tihan, T.; Szekeres, T.; Salamon, J.; Kraupp, M.; Eher, R.; Koller, U.; Knapp, W. Concordant changes of pyrimidine metabolism in blasts of two cases of acute myeloid leukemia after repeated treatment with ara-C in vivo. Leukemia 1990, 4 , 761-765.

122. Kawasaki, H.; Kuwabara, H.; Hori, H.; Higashigawa, M.; Ohkubo, T.; Sakurai, M. Intracellular dCTP/ara-CTP ratio and the cytotoxic effect of ara-C. Cancer Investig. 1991, 9, 409-413. [CrossRef] 
123. Tattersall, M.H.; Ganeshaguru, K.; Hoffbrand, A.V. Mechanisms of resistance of human acute leukaemia cells to cytosine arabinoside. Br. J. Haematol. 1974, 27, 39-46. [CrossRef] [PubMed]

124. Kanno, S.-i.; Hiura, T.; Ohtake, T.; Koiwai, K.; Suzuki, H.; Ujibe, M.; Ishikawa, M. Characterization of resistance to cytosine arabinoside (Ara-C) in NALM-6 human B leukemia cells. Clin. Chim. Acta 2007, 377, 144-149. [CrossRef]

125. Meuth, M. The molecular basis of mutations induced by deoxyribonucleoside triphosphate pool imbalances in mammalian cells. Exp. Cell Res. 1989, 181, 305-316. [CrossRef]

126. Verschuur, A.C.; Van Gennip, A.H.; Leen, R.; Voute, P.A.; Brinkman, J.; Van Kuilenburg, A.B. Cyclopentenyl cytosine increases the phosphorylation and incorporation into DNA of 1-beta-D-arabinofuranosyl cytosine in a human T-lymphoblastic cell line. Int. J. Cancer 2002, 98, 616-623. [CrossRef]

127. Shao, J.; Zhou, B.; Chu, B.; Yen, Y. Ribonucleotide reductase inhibitors and future drug design. Curr. Cancer Drug Targets 2006, 6, 409-431. [CrossRef]

128. Karp, J.E.; Giles, F.J.; Gojo, I.; Morris, L.; Greer, J.; Johnson, B.; Thein, M.; Sznol, M.; Low, J. A phase I study of the novel ribonucleotide reductase inhibitor 3-aminopyridine-2-carboxaldehyde thiosemicarbazone (3-AP, Triapine) in combination with the nucleoside analog fludarabine for patients with refractory acute leukemias and aggressive myeloproliferative disorders. Leuk. Res. 2008, 32, 71-77. [PubMed]

129. Gandhi, V.; Estey, E.; Keating, M.J.; Plunkett, W. Biochemical modulation of arabinosylcytosine for therapy of leukemias. Leuk. Lymphoma 1993, 10, 109-114. [CrossRef] [PubMed]

130. Gandhi, V.; Estey, E.; Du, M.; Nowak, B.; Keating, M.J.; Plunkett, W. Modulation of the cellular metabolism of cytarabine and fludarabine by granulocyte-colony-stimulating factor during therapy of acute myelogenous leukemia. Clin. Cancer Res. 1995, 1, 169-178.

131. Gandhi, V.; Kemena, A.; Keating, M.J.; Plunkett, W. Fludarabine infusion potentiates arabinosylcytosine metabolism in lymphocytes of patients with chronic lymphocytic leukemia. Cancer Res. 1992, 52, 897-903.

132. Dumontet, C.; Fabianowska-Majewska, K.; Mantincic, D.; Callet Bauchu, E.; Tigaud, I.; Gandhi, V.; Lepoivre, M.; Peters, G.J.; Rolland, M.O.; Wyczechowska, D.; et al. Common resistance mechanisms to deoxynucleoside analogues in variants of the human erythroleukaemic line K562. Br. J. Haematol. 1999, 106, 78-85. [CrossRef] [PubMed]

133. Hunsucker, S.A.; Mitchell, B.S.; Spychala, J. The 5'-nucleotidases as regulators of nucleotide and drug metabolism. Pharmacol. Ther. 2005, 107, 1-30. [CrossRef] [PubMed]

134. Cacciamani, T.; Vita, A.; Cristalli, G.; Vincenzetti, S.; Natalini, P.; Ruggieri, S.; Amici, A.; Magni, G. Purification of human cytidine deaminase: Molecular and enzymatic characterization and inhibition by synthetic pyrimidine analogs. Arch. Biochem. Biophys. 1991, 290, 285-292. [CrossRef]

135. Capizzi, R.L.; White, J.C.; Powell, B.L.; Perrino, F. Effect of dose on the pharmacokinetic and pharmacodynamic effects of cytarabine. Semin. Hematol. 1991, 28 (Suppl. 4), 54-69.

136. Fridland, A.; Verhoef, V. Mechanism for ara-CTP catabolism in human leukemic cells and effect of deaminase inhibitors on this process. Semin. Oncol. 1987, 14 (Suppl. 1), 262-268.

137. Liliemark, J.O.; Plunkett, W. Regulation of 1-beta-D-arabinofuranosylcytosine $5^{\prime}$-triphosphate accumulation in human leukemia cells by deoxycytidine 5'-triphosphate. Cancer Res. 1986, 46, 1079-1083.

138. Xu, P.P.; Chen, B.A.; Feng, J.F.; Cheng, L.; Xia, G.H.; Li, Y.F.; Qian, J.; Ding, J.H.; Lu, Z.H.; Wang, X.M.; et al. Association of polymorphisms of cytosine arabinoside-metabolizing enzyme gene with therapeutic efficacy for acute myeloid leukemia. Chin. Med. J. 2012, 125, 2137-2143.

139. Cao, Y.; Wang, X.; Cao, Z.; Wu, C.; Wu, D.; Cheng, X. Genetic polymorphisms of MBL2 and tuberculosis susceptibility: A metaanalysis of 22 case-control studies. Arch. Med. Sci. 2018, 14, 1212-1232. [CrossRef]

140. Zhu, K.W.; Chen, P.; Zhang, D.Y.; Yan, H.; Liu, H.; Cen, L.N.; Liu, Y.L.; Cao, S.; Zhou, G.; Zeng, H.; et al. Association of genetic polymorphisms in genes involved in Ara-C and dNTP metabolism pathway with chemosensitivity and prognosis of adult acute myeloid leukemia (AML). J. Transl. Med. 2018, 16, 90. [CrossRef]

141. McPherson, J.D.; Marra, M.; Hillier, L.; Waterston, R.H.; Chinwalla, A.; Wallis, J.; Sekhon, M.; Wylie, K.; Mardis, E.R.; Wilson, R.K.; et al. A physical map of the human genome. Nature 2001, 409, 934-941. [PubMed]

142. Cancer Genome Atlas Research Network. Comprehensive genomic characterization defines human glioblastoma genes and core pathways. Nature 2008, 455, 1061-1068. [CrossRef]

143. Huang, R.S.; Dolan, M.E. Approaches to the discovery of pharmacogenomic markers in oncology: 2000-2010-2020. Pharmacogenomics 2010, 11, 471-474. [CrossRef]

144. Garner, C. Upward bias in odds ratio estimates from genome-wide association studies. Genet. Epidemiol. 2007, 31, 288-295. [CrossRef]

145. Myers, S.N.; Goyal, R.K.; Roy, J.D.; Fairfull, L.D.; Wilson, J.W.; Ferrell, R.E. Functional single nucleotide polymorphism haplotypes in the human equilibrative nucleoside transporter 1. Pharm. Genom. 2006, 16, 315-320. [CrossRef]

146. Joerger, M.; Bosch, T.M.; Doodeman, V.D.; Beijnen, J.H.; Smits, P.H.; Schellens, J.H. Novel deoxycytidine kinase gene polymorphisms: A population screening study in Caucasian healthy volunteers. Eur. J. Clin. Pharmacol. 2006, 62, 681-684. [CrossRef]

147. Lamba, J.K.; Crews, K.; Pounds, S.; Schuetz, E.G.; Gresham, J.; Gandhi, V.; Plunkett, W.; Rubnitz, J.; Ribeiro, R. Pharmacogenetics of deoxycytidine kinase: Identification and characterization of novel genetic variants. J. Pharmacol. Exp. Ther. 2007, 323, 935-945. [CrossRef] [PubMed] 
148. Braunagel, D.; Schaich, M.; Kramer, M.; Dransfeld, C.L.; Ehninger, G.; Mahlknecht, U. The T_T genotype within the NME1 promoter single nucleotide polymorphism $-835 \mathrm{C} / \mathrm{T}$ is associated with an increased risk of cytarabine induced neurotoxicity in patients with acute myeloid leukemia. Leuk. Lymphoma 2012, 53, 952-957. [CrossRef] [PubMed]

149. Cao, X.; Mitra, A.K.; Pounds, S.; Crews, K.R.; Gandhi, V.; Plunkett, W.; Dolan, M.E.; Hartford, C.; Raimondi, S.; Campana, D.; et al. RRM1 and RRM2 pharmacogenetics: Association with phenotypes in HapMap cell lines and acute myeloid leukemia patients. Pharmacogenomics 2013, 14, 1449-1466. [CrossRef] [PubMed]

150. Carpi, F.M.; Vincenzetti, S.; Ubaldi, J.; Pucciarelli, S.; Polzonetti, V.; Micozzi, D.; Mignini, F.; Napolioni, V. CDA gene polymorphisms and enzyme activity: Genotype-phenotype relationship in an Italian-Caucasian population. Pharmacogenomics 2013, 14, 769-781. [CrossRef]

151. Mitra, A.K.; Crews, K.R.; Pounds, S.; Cao, X.; Feldberg, T.; Ghodke, Y.; Gandhi, V.; Plunkett, W.; Dolan, M.E.; Hartford, C.; et al. Genetic variants in cytosolic $5^{\prime}$-nucleotidase II are associated with its expression and cytarabine sensitivity in HapMap cell lines and in patients with acute myeloid leukemia. J. Pharmacol. Exp. Ther. 2011, 339, 9-23. [CrossRef]

152. Aksoy, P.; Zhu, M.J.; Kalari, K.R.; Moon, I.; Pelleymounter, L.L.; Eckloff, B.W.; Wieben, E.D.; Yee, V.C.; Weinshilboum, R.M.; Wang, L. Cytosolic 5'-nucleotidase III (NT5C3): Gene sequence variation and functional genomics. Pharm. Genom. 2009, 19, 567-576. [CrossRef]

153. Kuptsova-Clarkson, N.; Ambrosone, C.B.; Weiss, J.; Baer, M.R.; Sucheston, L.E.; Zirpoli, G.; Kopecky, K.J.; Ford, L.; Blanco, J.; Wetzler, M.; et al. XPD DNA nucleotide excision repair gene polymorphisms associated with DNA repair deficiency predict better treatment outcomes in secondary acute myeloid leukemia. Int. J. Mol. Epidemiol. Genet. 2010, 1, 278-294. [CrossRef]

154. Welsh, M.; Mangravite, L.; Medina, M.W.; Tantisira, K.; Zhang, W.; Huang, R.S.; McLeod, H.; Dolan, M.E. Pharmacogenomic discovery using cell-based models. Pharmacol. Rev. 2009, 61, 413-429. [CrossRef]

155. Wheeler, H.E.; Dolan, M.E. Lymphoblastoid cell lines in pharmacogenomic discovery and clinical translation. Pharmacogenomics 2012, 13, 55-70. [CrossRef] [PubMed]

156. Burdick, J.T.; Chen, W.M.; Abecasis, G.R.; Cheung, V.G. In silico method for inferring genotypes in pedigrees. Nat. Genet. 2006, 38, 1002-1004. [CrossRef]

157. Dausset, J.; Cann, H.; Cohen, D.; Lathrop, M.; Lalouel, J.M.; White, R. Centre d'etude du polymorphisme humain (CEPH): Collaborative genetic mapping of the human genome. Genomics 1990, 6, 575-577. [CrossRef]

158. Thorisson, G.A.; Smith, A.V.; Krishnan, L.; Stein, L.D. The International HapMap Project Web site. Genome Res. 2005, 15, 1592-1593. [CrossRef] [PubMed]

159. Wise, J. Consortium hopes to sequence genome of 1000 volunteers. BMJ 2008, 336, 237. [CrossRef] [PubMed]

160. Thorisson, G.A.; Stein, L.D. The SNP Consortium website: Past, present and future. Nucleic Acids Res. 2003, 31, 124-127. [CrossRef]

161. Morley, M.; Molony, C.M.; Weber, T.M.; Devlin, J.L.; Ewens, K.G.; Spielman, R.S.; Cheung, V.G. Genetic analysis of genome-wide variation in human gene expression. Nature 2004, 430, 743-747. [CrossRef]

162. Huang, R.S.; Duan, S.; Shukla, S.J.; Kistner, E.O.; Clark, T.A.; Chen, T.X.; Schweitzer, A.C.; Blume, J.E.; Dolan, M.E. Identification of genetic variants contributing to cisplatin-induced cytotoxicity by use of a genomewide approach. Am. J. Hum. Genet. 2007, 81, 427-437. [CrossRef] [PubMed]

163. Hartford, C.M.; Duan, S.; Delaney, S.M.; Mi, S.; Kistner, E.O.; Lamba, J.K.; Huang, R.S.; Dolan, M.E. Population-specific genetic variants important in susceptibility to cytarabine arabinoside cytotoxicity. Blood 2009, 113, 2145-2153. [CrossRef] [PubMed]

164. Gamazon, E.R.; Duan, S.; Zhang, W.; Huang, R.S.; Kistner, E.O.; Dolan, M.E.; Cox, N.J. PACdb: A database for cell-based pharmacogenomics. Pharm. Genom. 2010, 20, 269-273. [CrossRef]

165. Mackey, J.R.; Baldwin, S.A.; Young, J.D.; Cass, C.E. Nucleoside transport and its significance for anticancer drug resistance. Drug Resist. Updat. 1998, 1, 310-324. [CrossRef]

166. Leabman, M.K.; Huang, C.C.; DeYoung, J.; Carlson, E.J.; Taylor, T.R.; de la Cruz, M.; Johns, S.J.; Stryke, D.; Kawamoto, M.; Urban, T.J.; et al. Natural variation in human membrane transporter genes reveals evolutionary and functional constraints. Proc. Natl. Acad. Sci. USA 2003, 100, 5896-5901. [CrossRef]

167. Osato, D.H.; Huang, C.C.; Kawamoto, M.; Johns, S.J.; Stryke, D.; Wang, J.; Ferrin, T.E.; Herskowitz, I.; Giacomini, K.M. Functional characterization in yeast of genetic variants in the human equilibrative nucleoside transporter, ENT1. Pharmacogenetics 2003, 13, 297-301. [CrossRef] [PubMed]

168. Kim, S.R.; Saito, Y.; Maekawa, K.; Sugiyama, E.; Kaniwa, N.; Ueno, H.; Okusaka, T.; Morizane, C.; Yamamoto, N.; Ikeda, M.; et al. Thirty novel genetic variations in the SLC29A1 gene encoding human equilibrative nucleoside transporter 1 (hENT1). Drug Metab. Pharm. 2006, 21, 248-256. [CrossRef]

169. Stam, R.W.; den Boer, M.L.; Meijerink, J.P.; Ebus, M.E.; Peters, G.J.; Noordhuis, P.; Janka-Schaub, G.E.; Armstrong, S.A.; Korsmeyer, S.J.; Pieters, R. Differential mRNA expression of Ara-C-metabolizing enzymes explains Ara-C sensitivity in MLL gene-rearranged infant acute lymphoblastic leukemia. Blood 2003, 101, 1270-1276. [CrossRef] [PubMed]

170. Reiman, T.; Clarke, M.L.; Dabbagh, L.; Vsianska, M.; Coupland, R.W.; Belch, A.R.; Baldwin, S.A.; Young, J.D.; Cass, C.E.; Mackey, J.R. Differential expression of human equilibrative nucleoside transporter 1 (hENT1) protein in the Reed-Sternberg cells of Hodgkin's disease. Leuk. Lymphoma 2002, 43, 1435-1440. [CrossRef]

171. Kirschbaum, M. hENT1 and Hodgkin lymphoma: Not just crossing the channel. Leuk. Lymphoma 2008, 49, 1024-1025. [CrossRef] 
172. Lai, R.; Bartlett, N.L.; Mackey, J.R.; Jung, S.H.; Johnson, J.L.; Cook, J.R.; Jones, D.; Cass, C.E.; Young, J.D.; Said, J.; et al. High expression of nucleoside transporter protein hENT1 in Reed-Sternberg cells is associated with treatment failure in relapsed/refractory Hodgkin lymphoma patients treated with gemcitabine, vinorelbine and liposomal doxorubicin—a CALGB 59804 correlative study. Leuk. Lymphoma 2008, 49, 1202-1205.

173. Chow, L.; Lai, R.; Dabbagh, L.; Belch, A.; Young, J.D.; Cass, C.E.; Mackey, J.R. Analysis of human equilibrative nucleoside transporter 1 (hENT1) protein in non-Hodgkin's lymphoma by immunohistochemistry. Mod. Pathol. 2005, 18, 558-564. [CrossRef] [PubMed]

174. Guo, Y.; Kotova, E.; Chen, Z.S.; Lee, K.; Hopper-Borge, E.; Belinsky, M.G.; Kruh, G.D. MRP8, ATP-binding cassette C11 (ABCC11), is a cyclic nucleotide efflux pump and a resistance factor for fluoropyrimidines $2^{\prime}, 3^{\prime}$-dideoxycytidine and $9^{\prime}$-( $2^{\prime}$ phosphonylmethoxyethyl)adenine. J. Biol. Chem. 2003, 278, 29509-29514. [CrossRef] [PubMed]

175. Lu, X.; Gong, S.; Monks, A.; Zaharevitz, D.; Moscow, J.A. Correlation of nucleoside and nucleobase transporter gene expression with antimetabolite drug cytotoxicity. J. Exp. Ther. Oncol. 2002, 2, 200-212. [CrossRef]

176. Takagaki, K.; Katsuma, S.; Kaminishi, Y.; Horio, T.; Nakagawa, S.; Tanaka, T.; Ohgi, T.; Yano, J. Gene-expression profiling reveals down-regulation of equilibrative nucleoside transporter 1 (ENT1) in Ara-C-resistant CCRF-CEM-derived cells. J. Biochem. 2004, 136, 733-740. [CrossRef] [PubMed]

177. Cai, J.; Damaraju, V.L.; Groulx, N.; Mowles, D.; Peng, Y.; Robins, M.J.; Cass, C.E.; Gros, P. Two distinct molecular mechanisms underlying cytarabine resistance in human leukemic cells. Cancer Res. 2008, 68, 2349-2357. [CrossRef]

178. Zimmerman, E.I.; Huang, M.; Leisewitz, A.V.; Wang, Y.; Yang, J.; Graves, L.M. Identification of a novel point mutation in ENT1 that confers resistance to Ara-C in human T cell leukemia CCRF-CEM cells. FEBS Lett. 2009, 583, 425-429. [CrossRef]

179. Damaraju, V.L.; Damaraju, S.; Young, J.D.; Baldwin, S.A.; Mackey, J.; Sawyer, M.B.; Cass, C.E. Nucleoside anticancer drugs: The role of nucleoside transporters in resistance to cancer chemotherapy. Oncogene 2003, 22, 7524-7536. [CrossRef]

180. Naud, J.S.; Ghani, K.; de Campos-Lima, P.O.; Caruso, M. Nilotinib and imatinib inhibit cytarabine cellular uptake: Implications for combination therapy. Leuk. Res. 2012, 36, 1311-1314. [CrossRef] [PubMed]

181. Toyoda, Y.; Ishikawa, T. Pharmacogenomics of human ABC transporter ABCC11 (MRP8): Potential risk of breast cancer and chemotherapy failure. Anticancer Agents Med. Chem. 2010, 10, 617-624. [CrossRef] [PubMed]

182. Magdy, T.; Arlanov, R.; Winter, S.; Lang, T.; Klein, K.; Toyoda, Y.; Ishikawa, T.; Schwab, M.; Zanger, U.M. ABCC11/MRP8 polymorphisms affect 5-fluorouracil-induced severe toxicity and hepatic expression. Pharmacogenomics 2013, 14, 1433-1448. [CrossRef]

183. Gandhi, V.; Plunkett, W. Cell cycle-specific metabolism of arabinosyl nucleosides in K562 human leukemia cells. Cancer Chem. Pharmacol. 1992, 31, 11-17. [CrossRef]

184. Owens, J.K.; Shewach, D.S.; Ullman, B.; Mitchell, B.S. Resistance to 1-beta-D-arabinofuranosylcytosine in human T-lymphoblasts mediated by mutations within the deoxycytidine kinase gene. Cancer Res. 1992, 52, 2389-2393.

185. Van der Wilt, C.L.; Kroep, J.R.; Loves, W.J.; Rots, M.G.; Van Groeningen, C.J.; Kaspers, G.J.; Peters, G.J. Expression of deoxycytidine kinase in leukaemic cells compared with solid tumour cell lines, liver metastases and normal liver. Eur. J. Cancer 2003, 39, 691-697. [CrossRef]

186. Estey, E.; Plunkett, W.; Dixon, D.; Keating, M.; McCredie, K.; Freireich, E.J. Variables predicting response to high dose cytosine arabinoside therapy in patients with refractory acute leukemia. Leukemia 1987, 1, 580-583.

187. Raza, A.; Gezer, S.; Anderson, J.; Lykins, J.; Bennett, J.; Browman, G.; Goldberg, J.; Larson, R.; Vogler, R.; Preisler, H.D. Relationship of $[3 \mathrm{H}]$ Ara-C incorporation and response to therapy with high-dose Ara-C in AML patients: A Leukemia Intergroup study. Exp. Hematol. 1992, 20, 1194-1200.

188. Galmarini, C.M.; Thomas, X.; Graham, K.; El Jafaari, A.; Cros, E.; Jordheim, L.; Mackey, J.R.; Dumontet, C. Deoxycytidine kinase and $\mathrm{cN}-\mathrm{II}$ nucleotidase expression in blast cells predict survival in acute myeloid leukaemia patients treated with cytarabine. $\mathrm{Br}$. J. Haematol. 2003, 122, 53-60. [CrossRef]

189. Shi, J.Y.; Shi, Z.Z.; Zhang, S.J.; Zhu, Y.M.; Gu, B.W.; Li, G.; Bai, X.T.; Gao, X.D.; Hu, J.; Jin, W.; et al. Association between single nucleotide polymorphisms in deoxycytidine kinase and treatment response among acute myeloid leukaemia patients. Pharmacogenetics 2004, 14, 759-768. [CrossRef]

190. Szantai, E.; Ronai, Z.; Sasvari-Szekely, M.; Bonn, G.; Guttman, A. Multicapillary electrophoresis analysis of single-nucleotide sequence variations in the deoxycytidine kinase gene. Clin. Chem. 2006, 52, 1756-1762. [CrossRef]

191. Mahlknecht, U.; Dransfeld, C.L.; Bulut, N.; Kramer, M.; Thiede, C.; Ehninger, G.; Schaich, M. SNP analyses in cytarabine metabolizing enzymes in AML patients and their impact on treatment response and patient survival: Identification of CDA SNP C-451T as an independent prognostic parameter for survival. Leukemia 2009, 23, 1929-1932. [CrossRef]

192. Baker, J.A.; Wickremsinhe, E.R.; Li, C.H.; Oluyedun, O.A.; Dantzig, A.H.; Hall, S.D.; Qian, Y.W.; Ring, B.J.; Wrighton, S.A.; Guo, Y. Pharmacogenomics of gemcitabine metabolism: Functional analysis of genetic variants in cytidine deaminase and deoxycytidine kinase. Drug Metab. Dispos. 2013, 41, 541-545. [CrossRef]

193. Verschuur, A.C.; Brinkman, J.; Van Gennip, A.H.; Leen, R.; Vet, R.J.; Evers, L.M.; Voute, P.A.; Van Kuilenburg, A.B. Cyclopentenyl cytosine induces apoptosis and increases cytarabine-induced apoptosis in a T-lymphoblastic leukemic cell-line. Leuk. Res. 2001, 25, 891-900. [CrossRef] 
194. Verschuur, A.C.; van Gennip, A.H.; Leen, R.; Voute, P.A.; van Kuilenburg, A.B. Cyclopentenyl cytosine increases the phosphorylation and incorporation into dna of arabinofu-ranosyl cytosine in a myeloid leukemic cell-line. Adv. Exp. Med. Biol. 2000, 486, 311-317. [PubMed]

195. Rudd, S.G.; Tsesmetzis, N.; Sanjiv, K.; Paulin, C.B.; Sandhow, L.; Kutzner, J.; Hed Myrberg, I.; Bunten, S.S.; Axelsson, H.; Zhang, S.M.; et al. Ribonucleotide reductase inhibitors suppress SAMHD1 ara-CTPase activity enhancing cytarabine efficacy. EMBO Mol. Med. 2020, 12, e10419. [CrossRef]

196. Avramis, V.I.; Nandy, P.; Kwock, R.; Solorzano, M.M.; Mukherjee, S.K.; Danenberg, P.; Cohen, L.J. Increased p21/WAF-1 and p53 protein levels following sequential three drug combination regimen of fludarabine, cytarabine and docetaxel induces apoptosis in human leukemia cells. Anticancer Res. 1998, 18, 2327-2338.

197. Gandhi, V.; Estey, E.; Du, M.; Keating, M.J.; Plunkett, W. Minimum dose of fludarabine for the maximal modulation of 1-beta-Darabinofuranosylcytosine triphosphate in human leukemia blasts during therapy. Clin. Cancer Res. 1997, 3, $1539-1545$.

198. Kim, S.O.; Jeong, J.Y.; Kim, M.R.; Cho, H.J.; Ju, J.Y.; Kwon, Y.S.; Oh, I.J.; Kim, K.S.; Kim, Y.I.; Lim, S.C.; et al. Efficacy of gemcitabine in patients with non-small cell lung cancer according to promoter polymorphisms of the ribonucleotide reductase M1 gene. Clin. Cancer Res. 2008, 14, 3083-3088. [CrossRef] [PubMed]

199. Rha, S.Y.; Jeung, H.C.; Choi, Y.H.; Yang, W.I.; Yoo, J.H.; Kim, B.S.; Roh, J.K.; Chung, H.C. An association between RRM1 haplotype and gemcitabine-induced neutropenia in breast cancer patients. Oncologist 2007, 12, 622-630. [CrossRef]

200. Whelan, J.; Smith, T.; Phear, G.; Rohatiner, A.; Lister, A.; Meuth, M. Resistance to cytosine arabinoside in acute leukemia: The significance of mutations in CTP synthetase. Leukemia 1994, 8, 264-265.

201. Whelan, J.; Phear, G.; Yamauchi, M.; Meuth, M. Clustered base substitutions in CTP synthetase conferring drug resistance in Chinese hamster ovary cells. Nat. Genet. 1993, 3, 317-322. [CrossRef]

202. Fitzgerald, S.M.; Goyal, R.K.; Osborne, W.R.; Roy, J.D.; Wilson, J.W.; Ferrell, R.E. Identification of functional single nucleotide polymorphism haplotypes in the cytidine deaminase promoter. Hum. Genet. 2006, 119, 276-283. [CrossRef] [PubMed]

203. Schroder, J.K.; Kirch, C.; Seeber, S.; Schutte, J. Structural and functional analysis of the cytidine deaminase gene in patients with acute myeloid leukaemia. Br. J. Haematol. 1998, 103, 1096-1103. [CrossRef] [PubMed]

204. Yue, L.; Saikawa, Y.; Ota, K.; Tanaka, M.; Nishimura, R.; Uehara, T.; Maeba, H.; Ito, T.; Sasaki, T.; Koizumi, S. A functional single-nucleotide polymorphism in the human cytidine deaminase gene contributing to ara-C sensitivity. Pharmacogenetics 2003, 13, 29-38. [CrossRef]

205. Gilbert, J.A.; Salavaggione, O.E.; Ji, Y.; Pelleymounter, L.L.; Eckloff, B.W.; Wieben, E.D.; Ames, M.M.; Weinshilboum, R.M. Gemcitabine pharmacogenomics: Cytidine deaminase and deoxycytidylate deaminase gene resequencing and functional genomics. Clin. Cancer Res. 2006, 12, 1794-1803. [CrossRef]

206. Micozzi, D.; Carpi, F.M.; Pucciarelli, S.; Polzonetti, V.; Polidori, P.; Vilar, S.; Williams, B.; Costanzi, S.; Vincenzetti, S. Human cytidine deaminase: A biochemical characterization of its naturally occurring variants. Int. J. Biol. Macromol. 2013, 63C, 64-74. [CrossRef]

207. Iyer, S.N.; Ankala, A.; Singhal, R.S.; Hegde, M.R. Determination of common genetic variants in cytidine deaminase (CDA) gene in Indian ethnic population. Gene 2013, 524, 35-39. [CrossRef]

208. Jahns-Streubel, G.; Reuter, C.; Auf der Landwehr, U.; Unterhalt, M.; Schleyer, E.; Wormann, B.; Buchner, T.; Hiddemann, W. Activity of thymidine kinase and of polymerase alpha as well as activity and gene expression of deoxycytidine deaminase in leukemic blasts are correlated with clinical response in the setting of granulocyte-macrophage colony-stimulating factor-based priming before and during TAD-9 induction therapy in acute myeloid leukemia. Blood 1997, 90, 1968-1976.

209. Bhatla, D.; Gerbing, R.B.; Alonzo, T.A.; Conner, H.; Ross, J.A.; Meshinchi, S.; Zhai, X.; Zamzow, T.; Mehta, P.A.; Geiger, H.; et al. Cytidine deaminase genotype and toxicity of cytosine arabinoside therapy in children with acute myeloid leukemia. $\mathrm{Br}$. $J$. Haematol. 2009, 144, 388-394. [CrossRef]

210. Galmarini, C.M.; Cros, E.; Thomas, X.; Jordheim, L.; Dumontet, C. The prognostic value of cN-II and cN-III enzymes in adult acute myeloid leukemia. Haematologica 2005, 90, 1699-1701.

211. Galmarini, C.M.; Graham, K.; Thomas, X.; Calvo, F.; Rousselot, P.; El Jafaari, A.; Cros, E.; Mackey, J.R.; Dumontet, C. Expression of high $\mathrm{Km} 5^{\prime}$-nucleotidase in leukemic blasts is an independent prognostic factor in adults with acute myeloid leukemia. Blood 2001, 98, 1922-1926. [CrossRef] [PubMed]

212. Yamauchi, T.; Negoro, E.; Kishi, S.; Takagi, K.; Yoshida, A.; Urasaki, Y.; Iwasaki, H.; Ueda, T. Intracellular cytarabine triphosphate production correlates to deoxycytidine kinase/cytosolic $5^{\prime}$-nucleotidase II expression ratio in primary acute myeloid leukemia cells. Biochem. Pharmacol. 2009, 77, 1780-1786. [CrossRef]

213. Jordheim, L.P.; Marton, Z.; Rhimi, M.; Cros-Perrial, E.; Lionne, C.; Peyrottes, S.; Dumontet, C.; Aghajari, N.; Chaloin, L. Identification and characterization of inhibitors of cytoplasmic $5^{\prime}$-nucleotidase cN-II issued from virtual screening. Biochem. Pharmacol. 2013, 85, 497-506. [CrossRef]

214. Helleday, T.; Petermann, E.; Lundin, C.; Hodgson, B.; Sharma, R.A. DNA repair pathways as targets for cancer therapy. Nat. Rev. Cancer 2008, 8, 193-204. [CrossRef]

215. Liu, X.; Wang, Y.; Benaissa, S.; Matsuda, A.; Kantarjian, H.; Estrov, Z.; Plunkett, W. Homologous recombination as a resistance mechanism to replication-induced double-strand breaks caused by the antileukemia agent CNDAC. Blood 2010, 116, 1737-1746. [CrossRef] [PubMed] 
216. Giachino, D.F.; Ghio, P.; Regazzoni, S.; Mandrile, G.; Novello, S.; Selvaggi, G.; Gregori, D.; DeMarchi, M.; Scagliotti, G.V. Prospective assessment of XPD Lys751Gln and XRCC1 Arg399Gln single nucleotide polymorphisms in lung cancer. Clin. Cancer Res. 2007, 13, 2876-2881. [CrossRef] [PubMed]

217. Shi, J.Y.; Ren, Z.H.; Jiao, B.; Xiao, R.; Yun, H.Y.; Chen, B.; Zhao, W.L.; Zhu, Q.; Chen, Z.; Chen, S.J. Genetic variations of DNA repair genes and their prognostic significance in patients with acute myeloid leukemia. Int. J. Cancer 2011, 128, 233-238. [CrossRef] [PubMed]

218. Yin, G.; Zheng, Q.; Yan, C.; Berk, B.C. GIT1 is a scaffold for ERK1/2 activation in focal adhesions. J. Biol. Chem. 2005, 280, 27705-27712. [CrossRef] [PubMed]

219. Lu, Z.; Xu, S. ERK1/2 MAP kinases in cell survival and apoptosis. IUBMB Life 2006, 58, 621-631. [CrossRef]

220. Shaw, G.C.; Cope, J.J.; Li, L.; Corson, K.; Hersey, C.; Ackermann, G.E.; Gwynn, B.; Lambert, A.J.; Wingert, R.A.; Traver, D.; et al. Mitoferrin is essential for erythroid iron assimilation. Nature 2006, 440, 96-100. [CrossRef]

221. Leardi, A.; Caraglia, M.; Selleri, C.; Pepe, S.; Pizzi, C.; Notaro, R.; Fabbrocini, A.; De Lorenzo, S.; Musico, M.; Abbruzzese, A.; et al. Desferioxamine increases iron depletion and apoptosis induced by ara-C of human myeloid leukaemic cells. Br. J. Haematol. 1998, 102, 746-752. [CrossRef]

222. Mitra, A.K.; Crews, K.; Pounds, S.; Cao, X.; Downing, J.R.; Raimondi, S.; Campana, D.; Ribeiro, R.C.; Rubnitz, J.E.; Lamba, J.K. Impact of genetic variation in FKBP5 on clinical response in pediatric acute myeloid leukemia patients: A pilot study. Leukemia 2011, 25, 1354-1356. [CrossRef]

223. Xie, C.; Drenberg, C.; Edwards, H.; Caldwell, J.T.; Chen, W.; Inaba, H.; Xu, X.; Buck, S.A.; Taub, J.W.; Baker, S.D.; et al. Panobinostat enhances cytarabine and daunorubicin sensitivities in AML cells through suppressing the expression of BRCA1, CHK1, and Rad51. PLoS ONE 2013, 8, e79106. [CrossRef] [PubMed]

224. Children's Oncology Group; Aplenc, R.; Alonzo, T.A.; Gerbing, R.B.; Smith, F.O.; Meshinchi, S.; Ross, J.A.; Perentesis, J.; Woods, W.G.; Lange, B.J.; et al. Ethnicity and survival in childhood acute myeloid leukemia: A report from the Children's Oncology Group. Blood 2006, 108, 74-80. [CrossRef]

225. Sekeres, M.A.; Peterson, B.; Dodge, R.K.; Mayer, R.J.; Moore, J.O.; Lee, E.J.; Kolitz, J.; Baer, M.R.; Schiffer, C.A.; Carroll, A.J.; et al. Differences in prognostic factors and outcomes in African Americans and whites with acute myeloid leukemia. Blood 2004, 103, 4036-4042. [CrossRef] [PubMed]

226. Rubnitz, J.E.; Lensing, S.; Razzouk, B.I.; Pounds, S.; Pui, C.H.; Ribeiro, R.C. Effect of race on outcome of white and black children with acute myeloid leukemia: The St. Jude experience. Pediatr. Blood Cancer 2007, 48, 10-15. [CrossRef]

227. Pearson, T.A.; Manolio, T.A. How to interpret a genome-wide association study. JAMA 2008, 299, 1335-1344. [CrossRef] [PubMed]

228. Gamazon, E.R.; Lamba, J.K.; Pounds, S.; Stark, A.L.; Wheeler, H.E.; Cao, X.; Im, H.K.; Mitra, A.K.; Rubnitz, J.E.; Ribeiro, R.C.; et al. Comprehensive genetic analysis of cytarabine sensitivity in a cell-based model identifies polymorphisms associated with outcome in AML patients. Blood 2013, 121, 4366-4376. [CrossRef]

229. Zeggini, E.; Ioannidis, J.P. Meta-analysis in genome-wide association studies. Pharmacogenomics 2009, 10, 191-201. [CrossRef]

230. Higgins, J.P.; Thompson, S.G.; Deeks, J.J.; Altman, D.G. Measuring inconsistency in meta-analyses. BMJ 2003, 327, 557-560. [CrossRef]

231. Salanti, G.; Higgins, J.P.; Trikalinos, T.A.; Ioannidis, J.P. Bayesian meta-analysis and meta-regression for gene-disease associations and deviations from Hardy-Weinberg equilibrium. Stat. Med. 2007, 26, 553-567. [CrossRef]

232. Fridley, B.L.; Serie, D.; Jenkins, G.; White, K.; Bamlet, W.; Potter, J.D.; Goode, E.L. Bayesian mixture models for the incorporation of prior knowledge to inform genetic association studies. Genet. Epidemiol. 2010, 34, 418-426. [CrossRef] [PubMed]

233. Visscher, P.M.; Brown, M.A.; McCarthy, M.I.; Yang, J. Five years of GWAS discovery. Am. J. Hum. Genet. 2012, 90, 7-24. [CrossRef]

234. Tirelli, U.; Berretta, M.; Bearz, A.; Carbone, A. Grouping of molecularly targeted anti-cancer agents based on cost-effectiveness analysis. Eur. Rev. Med. Pharmacol. Sci. 2011, 15, 1355-1356. [PubMed]

235. Payne, K.; Shabaruddin, F.H. Cost-effectiveness analysis in pharmacogenomics. Pharmacogenomics 2010, 11, 643-646. [CrossRef]

236. Dhalla, I.A.; Garner, S.; Chalkidou, K.; Littlejohns, P. Perspectives on the National Institute for Health and Clinical Excellence's recommendations to use health technologies only in research. Int. J. Technol. Assess. Health Care 2009, 25, 272-280. [CrossRef] [PubMed]

237. Biondi, A.; Cazzaniga, G. Novel clinical trials for pediatric leukemias: Lessons learned from genomic analyses. Hematology Am. Soc. Hematol. Educ. Program. 2013, 2013, 612-619. [CrossRef]

238. Adema, A.D.; Smid, K.; Losekoot, N.; Honeywell, R.J.; Verheul, H.M.; Myhren, F.; Sandvold, M.L.; Peters, G.J. Metabolism and accumulation of the lipophilic deoxynucleoside analogs elacytarabine and CP-4126. Investig. New Drugs 2012, 30, 1908-1916. [CrossRef] [PubMed]

239. Giles, F.J.; Vey, N.; Rizzieri, D.; Ravandi, F.; Prebet, T.; Borthakur, G.; Jacobsen, T.F.; Hagen, S.; Nilsson, B.; O’Brien, S. Phase I and pharmacokinetic study of elacytarabine, a novel $5^{\prime}$-elaidic acid derivative of cytarabine, in adults with refractory hematological malignancies. Leukemia 2012, 26, 1686-1689. [CrossRef]

240. Robinson, G.M.; Anderson, E.; Salisbury, V.C.; Mehta, P.A.; Sandvold, M.L.; Reynolds, D.M. Detection of intracellular ara$\mathrm{C}$ /ara-CTP following treatment with the new anti-leukemic drug elacytarabine using a bioluminescent bacterial biosensor. In Proceedings of the AACR Annual Meeting, Washington, DC, USA, 6-10 April 2013. 
241. Roboz, G.J.; Rosenblat, T.; Arellano, M.; Gobbi, M.; Altman, J.K.; Montesinos, P.; O’Connell, C.; Solomon, S.R.; Pigneux, A.; Vey, N.; et al. International randomized phase III study of elacytarabine versus investigator choice in patients with relapsed/refractory acute myeloid leukemia. J. Clin. Oncol. 2014, 32, 1919-1926. [CrossRef]

242. Kantarjian, H.; Faderl, S.; Garcia-Manero, G.; Luger, S.; Venugopal, P.; Maness, L.; Wetzler, M.; Coutre, S.; Stock, W.; Claxton, D.; et al. Oral sapacitabine for the treatment of acute myeloid leukaemia in elderly patients: A randomised phase 2 study. Lancet Oncol. 2012, 13, 1096-1104. [CrossRef]

243. Hanaoka, K.; Suzuki, M.; Kobayashi, T.; Tanzawa, F.; Tanaka, K.; Shibayama, T.; Miura, S.; Ikeda, T.; Iwabuchi, H.; Nakagawa, A.; et al. Antitumor activity and novel DNA-self-strand-breaking mechanism of CNDAC (1-(2-C-cyano-2-deoxy-beta-D-arabinopentofuranosyl) cytosine) and its N4-palmitoyl derivative (CS-682). Int. J. Cancer 1999, 82, 226-236. [CrossRef]

244. Ewald, B.; Sampath, D.; Plunkett, W. Nucleoside analogs: Molecular mechanisms signaling cell death. Oncogene 2008, 27, 6522-6537. [CrossRef]

245. Liu, X.; Guo, Y.; Li, Y.; Jiang, Y.; Chubb, S.; Azuma, A.; Huang, P.; Matsuda, A.; Hittelman, W.; Plunkett, W. Molecular basis for G2 arrest induced by 2 '-C-cyano-2'-deoxy-1-beta-D-arabino-pentofuranosylcytosine and consequences of checkpoint abrogation. Cancer Res. 2005, 65, 6874-6881. [CrossRef]

246. Jordheim, L.P.; Cros, E.; Gouy, M.H.; Galmarini, C.M.; Peyrottes, S.; Mackey, J.; Perigaud, C.; Dumontet, C. Characterization of a gemcitabine-resistant murine leukemic cell line: Reversion of in vitro resistance by a mononucleotide prodrug. Clin. Cancer Res. 2004, 10, 5614-5621. [CrossRef] [PubMed]

247. Tobias, S.C.; Borch, R.F. Synthesis and biological evaluation of a cytarabine phosphoramidate prodrug. Mol. Pharm. 2004, 1, 112-116. [CrossRef]

248. Gouy, M.H.; Jordheim, L.P.; Lefebvre, I.; Cros, E.; Dumontet, C.; Peyrottes, S.; Perigaud, C. Special feature of mixed phosphotriester derivatives of cytarabine. Bioorg. Med. Chem. 2009, 17, 6340-6347. [CrossRef] [PubMed]

249. Senanayake, T.H.; Warren, G.; Wei, X.; Vinogradov, S.V. Application of activated nucleoside analogs for the treatment of drug-resistant tumors by oral delivery of nanogel-drug conjugates. J. Control. Release 2013, 167, 200-209. [CrossRef] [PubMed]

250. Chamberlain, M.C. Neurotoxicity of intra-CSF liposomal cytarabine (DepoCyt) administered for the treatment of leptomeningeal metastases: A retrospective case series. J. Neurooncol. 2012, 109, 143-148. [CrossRef]

251. Hilgendorf, I.; Wolff, D.; Junghanss, C.; Kahl, C.; Leithaeuser, M.; Steiner, B.; Casper, J.; Freund, M. Neurological complications after intrathecal liposomal cytarabine application in patients after allogeneic haematopoietic stem cell transplantation. Ann. Hematol. 2008, 87, 1009-1012. [CrossRef] [PubMed]

252. Jabbour, E.; O’Brien, S.; Kantarjian, H.; Garcia-Manero, G.; Ferrajoli, A.; Ravandi, F.; Cabanillas, M.; Thomas, D.A. Neurologic complications associated with intrathecal liposomal cytarabine given prophylactically in combination with high-dose methotrexate and cytarabine to patients with acute lymphocytic leukemia. Blood 2007, 109, 3214-3218. [CrossRef]

253. Ostermann, K.; Pels, H.; Kowoll, A.; Kuhnhenn, J.; Schlegel, U. Neurologic complications after intrathecal liposomal cytarabine in combination with systemic polychemotherapy in primary CNS lymphoma. J. Neurooncol. 2011, 103, 635-640. [CrossRef] [PubMed]

254. Corazzelli, G.; Frigeri, F.; Russo, F.; Frairia, C.; Arcamone, M.; Esposito, G.; De Chiara, A.; Morelli, E.; Capobianco, G.; Becchimanzi, C.; et al. RD-CODOX-M/IVAC with rituximab and intrathecal liposomal cytarabine in adult Burkitt lymphoma and 'unclassifiable' highly aggressive B-cell lymphoma. Br. J. Haematol. 2012, 156, 234-244. [CrossRef]

255. Spina, M.; Chimienti, E.; Martellotta, F.; Vaccher, E.; Berretta, M.; Zanet, E.; Lleshi, A.; Canzonieri, V.; Bulian, P.; Tirelli, U. Phase 2 study of intrathecal, long-acting liposomal cytarabine in the prophylaxis of lymphomatous meningitis in human immunodeficiency virus-related non-Hodgkin lymphoma. Cancer 2010, 116, 1495-1501. [CrossRef] [PubMed]

256. Federico, C.; Morittu, V.M.; Britti, D.; Trapasso, E.; Cosco, D. Gemcitabine-loaded liposomes: Rationale, potentialities and future perspectives. Int. J. Nanomed. 2012, 7, 5423-5436.

257. Feldman, E.J.; Lancet, J.E.; Kolitz, J.E.; Ritchie, E.K.; Roboz, G.J.; List, A.F.; Allen, S.L.; Asatiani, E.; Mayer, L.D.; Swenson, C.; et al. First-in-man study of CPX-351: A liposomal carrier containing cytarabine and daunorubicin in a fixed 5:1 molar ratio for the treatment of relapsed and refractory acute myeloid leukemia. J. Clin. Oncol. 2011, 29, 979-985. [CrossRef]

258. International HapMap Consortium. The International HapMap Project. Nature 2003, 426, 789-796. [CrossRef] [PubMed]

259. International HapMap Consortium. A haplotype map of the human genome. Nature 2005, 437, 1299-1320. [CrossRef]

260. Genomes Project, C.; Abecasis, G.R.; Auton, A.; Brooks, L.D.; DePristo, M.A.; Durbin, R.M.; Handsaker, R.E.; Kang, H.M.; Marth, G.T.; McVean, G.A. An integrated map of genetic variation from 1,092 human genomes. Nature 2012, 491, 56-65.

261. 1000 Genomes Project Consortium; Abecasis, G.R.; Altshuler, D.; Auton, A.; Brooks, L.D.; Durbin, R.M.; Gibbs, R.A.; Hurles, M.E.; McVean, G.A. A map of human genome variation from population-scale sequencing. Nature 2010, 467, 1061-1073. [CrossRef] 